\title{
O gênero Miconia (Melastomataceae) no Estado do Paraná, Brasil
}

\author{
Renato Goldenberg ${ }^{1}$
}

Recebido em 24/10/2003. Aceito em 02/06/2004

\begin{abstract}
RESUMO - (O gênero Miconia (Melastomataceae) no Estado do Paraná, Brasil). O gênero Miconia Ruiz \& Pav. apresenta 32 espécies no Estado do Paraná. Estas espécies estão concentradas principalmente no leste do Estado (regiões litorânea, da Serra do Mar e do Primeiro Planalto) e pertencem a sete das 11 seções do gênero, sendo as mais relevantes Glossocentrum (14 spp.) e Miconia (7 spp.). Neste trabalho são apresentadas chave de identificação, descrições e listas de materiais selecionados para as espécies de Miconia do Paraná.
\end{abstract}

Palavras-chave: Melastomataceae, Miconia, Paraná, Brasil

\begin{abstract}
The genus Miconia (Melastomataceae) in the State of Paraná, Brazil). The genus Miconia Ruiz \& Pav. presents 32 species in the State of Paraná (Brazil). These species occur mostly at the eastern portion of the state (coastal region, "Serra do Mar” and "Primeiro Planalto") and belong to seven sections (from a total 11 in the genus); the most important sections are Glossocentrum (14 spp.) and Miconia (7 spp.). This work presents an identification key, descriptions and selected collection lists for the Miconia species from State of Paraná.
\end{abstract}

Key words: Melastomataceae, Miconia, State Paraná, Brazil

\section{Introdução}

A família Melastomataceae apresenta cerca de 4.570 espécies distribuídas pelas regiões tropicais e subtropicais de todo o globo (Clausing \& Renner 2001). Cerca de um quarto destas espécies (1.056, segundo Goldenberg \& Almeida, in prep.) pertencem ao gênero Miconia, que ocorre desde o sul do México até o norte da Argentina e Uruguai. Da forma pela qual está atualmente delimitado, este gênero pode ser reconhecido pelas folhas destituídas de formicários, inflorescências geralmente terminais e não envoltas por brácteas foliosas, hipanto sem constrição no ápice, cálice com lacínias externas reduzidas, pétalas com ápice arredondado ou emarginado, nunca agudo, e frutos bacáceos (Goldenberg \& Almeida, in prep.).

A última revisão completa de Miconia foi elaborada ainda no século XIX (Cogniaux 1891). Para o Brasil, após a monografia da Flora Brasiliensis (Cogniaux 1886-1888) foram publicados tratamentos taxonômicos para os Estados do Rio de Janeiro (Pereira 1964; Baumgratz 1980; 1982; 1984), Santa Catarina (Wurdack 1962) e São Paulo (Martins et al. 1996). Para o Paraná existe publicada apenas uma listagem com 28 espécies (Angely 1965).
A classificação infragenérica utilizada hoje para o gênero (Goldenberg \& Almeida, in prep.) ainda é aquela proposta por Triana (1871) e modificada por Cogniaux (1891). Este último reconheceu 11 seções, estabelecidas a partir de características morfológicas relativas ao hipanto, cálice, pétalas e, principalmente, aos estames.

Tendo em vista a ocorrência de espécies de Miconia - e de Melastomataceae em geral - em quase todas as formações fitogeográficas do Paraná e a enorme quantidade de coletas depositadas nos herbários paranaenses, este trabalho tem como objetivo preencher uma lacuna nos trabalhos sobre a Flora do Paraná, onde nada foi feito sobre esta família. No trabalho aqui apresentado foram elaboradas chave de identificação, descrições e distribuição geográfica de todas as espécies de Miconia ocorrentes no Estado.

\section{Material e métodos}

As exsicatas analisadas neste trabalho foram obtidas nos herbários paranaenses EFC, FUEL, HUEPG, HUCP, HUM, MBM, UPCB (siglas segundo The New York Botanical Garden 2004). Análises adicionais foram efetuadas nas coleções de

\footnotetext{
1 Departamento de Botânica, Setor de Ciências Biológicas, Universidade Federal do Paraná, C. Postal 19031, CEP 81531-970, Curitiba, PR, Brasil (rgolden@ufpr.br).Bolsista produtividade, CNPq
} 
R, SP, UEC e US. Para cada espécie, apenas as coletas provenientes do Estado do Paraná foram listadas como "material selecionado", e apenas uma coleta por município foi citada. Uma lista completa do material examinado encontra-se à disposição com o autor. As descrições basearam-se, sempre que possível, em coletas provenientes do Estado, mas algumas espécies pobres em coletas tiveram suas descrições complementadas com coletas de Estados vizinhos, neste caso indicadas como "material adicional”.

Caracteres típicos ocorrendo em apenas uma espécie ou grupo não foram descritos para as demais. É o caso do caule com projeções interpeciolares (M. cinnamomifolia), ramos alados (M. willdenowii), pecíolos alados (M. prasina), número de glomérulos nos ramos basais das inflorescências (espécies com inflorescências glomeruladas das seções Glossocentrum e Cremanium), flores pediceladas (M. splendens), presença de tricomas glandulares nas margens das pétalas e estilete ( $M$. cinerascens var. robusta e $M$. stenostachya) ou no conectivo (M. cinerascens var. robusta e M. langsdorffii). O número de nervuras das folhas foi complementado com um sinal de "mais" e o número dois quando constatou-se a ocorrência de um par submarginal tênue adicional (por exemplo: $3+2$, com 3 nervuras principais e mais o par tênue).

As espécies estão dispostas em ordem alfabética. A distribuição das espécies pelas seções segue Cogniaux (1891, com modificações) . Táxons infraespecíficos foram aceitos apenas em dois casos (M. cinerascens e $M$. tristis), onde a separação mostrou-se consistente. Para a listagem de sinonímias de cada espécie ver Goldenberg (2000). As distribuições geográficas das espécies foram obtidas a partir de Goldenberg (2000) e de banco de dados pessoal do autor.

O Estado do Paraná - O Paraná situa-se na Região Sul do Brasil, entre as latitudes de $22^{\circ} 29^{\prime}$ e $26^{\circ} 42^{\prime} \mathrm{S}$ e longitudes de $48^{\circ} 02^{\prime}$ e $54^{\circ} 37^{\prime} \mathrm{W}$, limitando-se ao norte com o São Paulo, a leste com o Oceano Atlântico, ao sul com Santa Catarina e a oeste com Mato Grosso do Sul, Paraguai e Argentina.

O Estado tradicionalmente é dividido em cinco zonas de paisagens naturais (Maack 1968): a região litorânea limita-se à leste pelo Oceano e a oeste pelas escarpas do complexo cristalino que forma a segunda região, a da Serra do Mar. Acima desta começa o Primeiro Planalto, cuja altitude diminui no sentido oeste, até as escarpas formadas por sedimentos paleozóicos, que representam o limite da região seguinte, o Segundo Planalto. Este limita-se a oeste com o Terceiro Planalto, acima da série seguinte de escarpas constituídas por formações mesozóicas. Os rios mais importantes pertencem à bacia do Paraná (que limita o Estado a oeste), nascendo no Primeiro ou Segundo Planaltos e correndo em direção a oeste. São eles (ordenados desde o sul até o norte): Iguaçú, Piqueri, Ivaí e Paranapanema. No norte do Estado são importantes os afluentes do Paranapanema (Tibagi, Laranjinha e Cinzas) e a bacia do rio Ribeira.

Três tipos de clima são encontrados no Paraná (IAPAR 1994). A região litorânea e a porção noroeste do Primeiro Planalto (Vale do Ribeira) apresentam clima tropical superúmido, sem estação seca, com temperatura média em todos os meses superior a $18^{\circ} \mathrm{C}$ e isento de geadas. O restante do Primeiro Planalto, as porções centrais e meridionais do Segundo e a porção sudeste do Terceiro Planalto apresentam clima temperado, com temperatura média no mês mais frio abaixo de $18^{\circ} \mathrm{C}$ e no mês mais quente abaixo de $22^{\circ} \mathrm{C}$, verões frescos, sem estação seca definida e com geadas freqüentes. A porção setentrional do Segundo Planalto, mais parte das bacias dos rios Ivaí e Tibagi, e o restante do Terceiro Planalto apresentam clima subtropical, com temperatura média no mês mais frio inferior a $18^{\circ} \mathrm{C}$ e no mais quente acima de $22^{\circ} \mathrm{C}$, com verões quentes, geadas pouco freqüentes e tendência de concentração das chuvas nos meses de verão, mas sem estação seca definida.

Os principais tipos de vegetação do Estado são (Leite 1994): 1. Floresta Ombrófila Densa, no litoral e Serra do Mar, com os subtipos Altomontana (acima de $1.000 \mathrm{~m})$, Montana (400-1.000m), Submontana (30-400m) e de Terras Baixas (até 30m), além de formações associadas (refúgios ou campos de altitude; formações pioneiras ou restinga e mangue); 2 . Floresta Ombrófila Mista, nas regiões mais altas ao sul da região planaltina; 3. Estepe Ombrófila (Campos Gerais) nas mesmas regiões; 4. Floresta Estacional Semidecidual Subxérica (norte e oeste do Segundo e Terceiro Planaltos); 5. Savana Estacional Subxérica (Cerrado), no nordeste do Estado.

\section{Resultados e discussão}

\section{Miconia Ruiz \& Pav.}

Arbustos ou árvores com indumento variável ou glabros. Folhas opostas ou verticiladas, pecioladas ou sésseis, com nervação acródroma. Panículas terminais, 
raro com ramos adicionais axilares; inflorescências parciais dicasiais, glomeruladas, espiciformes ou escorpióides; brácteas persistentes ou caducas, muitas vezes ainda nos botões. Flores 5-meras, raro 4, 6 ou 8-meras; hipanto campanulado a cilíndrico; cálice simples ou duplo, em geral regularmente lobado e usualmente com lacínias externas pouco conspícuas, persistente ou caduco; pétalas brancas, raro rosadas, arredondadas ou retusas no ápice, raro apiculadas, glabras ou papilosas; estames dimorfos ou isomorfos; filetes geralmente glabros, anteras de forma variável, amarelas, brancas ou roxas, uniporosas, raro 2 ou 4-porosas ou rimosas; conectivo simples ou basalmente prolongado, com ou sem apêndices dorsais ou ventrais; ovário (1-)2-5-locular, semi-ínfero a ínfero. Fruto bacáceo; 1 ou várias sementes, piramidais a ovais.

Comentários e distribuição geográfica: no Paraná ocorrem 32 espécies de Miconia; pertencentes a sete seções: Glossocentrum (Crueger) Hook. f. (14 spp.), Miconia (7 spp.), Cremanium (D. Don) Hook.f. (4 spp.), Hypoxanthus (Rich. ex DC.) Hook. f. (antiga seção Chaenanthera (Naudin) Cogn., 3 spp.), Jucunda (Cham.) Triana (2 spp.) Tamonea Cogn. (1 sp.) e Amblyarrhena (Naudin) Triana (1 sp.). Entre as 32 espécies, 12 são exclusivas do Litoral, Serra do
Mar e norte do Primeiro Planalto (Vale do Ribeira), enquanto que 11 são exclusivas do planalto paranaense. A concentração de espécies de Miconia no leste do Estado é mais visível quando se constata que 26 das 32 espécies confirmadas foram coletadas no Litoral, Serra do Mar e Primeiro Planalto. Cerca de um terço das espécies (13) apresenta uma distribuição relativamente ampla, ocorrendo em ao menos três das cinco regiões do Estado.

No Paraná, Miconia distingue-se dos demais gêneros de Melastomataceae com frutos bacáceos (excluindo-se Mouriri Aubl., que pertence a Memecylaceae segundo Clausing \& Renner 2001) pelo crescimento terrestre (epifítico em Pleiochiton Naudin e em uma espécie de Clidemia D. Don), pelas inflorescências terminais (pseudolaterais ou laterais em Clidemia e laterais em Ossaea DC.) e pelas pétalas com ápice arredondado ou emarginado (agudo em Leandra Raddi).

As espécies de Miconia no Paraná são popularmente designadas por "pixirica” ou "jacatirão". Cada um destes nomes é utilizado para várias espécies e algumas espécies ( $M$. cinerascens, $M$. sellowiana e $M$. theaezans) são chamadas por nomes diferentes.

Chave para as espécies de Miconia no Estado do Paraná

1. Folhas adultas com face abaxial glabra, às vezes com tricomas apenas sobre as nervuras

2. Ramos novos com projeções interpeciolares (Fig. 4)

7. M. cinnamomifolia

2. Ramos novos sem projeções interpeciolares

3. Inflorescências terminais e laterais

4. Nervuras acródromas basais (Fig. 5)

19. M. latecrenata

4. Nervuras acródromas suprabasais (Fig. 6)

5. Nervura central unida ao par interno por membrana, formando domácia ..... 12. M. doriana

5. Nervura central não unida ao par interno por membrana 30. M. tristis

3. Inflorescências exclusivamente terminais

6. Nervuras acródromas basais (Fig. 5)

7. Flores com anteras amarelas

8. Panículas 2-2,5cm compr.; cálice persistente; anteras 3-4,2mm 25. M. ramboi

8. Panículas 4,5-14,3cm compr.; cálice caduco; anteras 6-8,5mm 17. M. jucunda

7. Flores com anteras brancas ou creme

9. Anteras deiscentes através de abertura longitudinal 24. M. pusilliflora

9. Anteras deiscentes através de 1-4 poros apicais

10. Anteras deiscentes através de 4 poros 29. M. theaezans

10. Anteras deiscentes através de 1-2 poros (Fig. 19-22)

11. Cálice persistente; ovário com tricomas no ápice 22. M. petropolitana 11. Cálice caduco; ovário com ápice glabro

12. Cálice com verticilo interno truncado, sem lacínias distintas (Fig. 17-18) 8. M. collatata 
12. Cálice com verticilo interno formado por lacínias bem definidas, arredondadas ou triangulares (Fig. 14-15) 20. M. ligustroides

6. Nervuras acródromas suprabasais (Fig. 6)

13. Nervura central unida ao par interno por membrana, formando domácia

14. Anteras deiscentes através de uma abertura longitudinal abrangendo desde o ápice até a base da antera 24. M. pusilliflora

14. Anteras deiscentes através de um poro apical ou de uma abertura longitudinal abrangendo no máximo 1/3 do comprimento da antera

15. Cálice com lacínias internas triangulares; estames 16-20 12. M. doriana

15. Cálice com lacínias internas arredondadas; estames 10 26. M. sellowiana

13. Nervura central não unida ao par interno por membrana

16. Cálice persistente

17. Folhas com margem inteira a ondulada; hipanto glabro

4. M. chamissois

17. Folhas com margem denticulada na metade distal; hipanto com tricomas

23. M. prasina

16. Cálice caduco

18. Folhas com base longamente atenuada

19. Folhas com margem crenulada; panículas de glomérulos

10. M. discolor

19. Folhas com margem denticulada; panículas não de glomérulos... 27. M. splendens

18. Folhas com base aguda, obtusa, truncada até subcordada

20. Anteras brancas

20. M. ligustroides

20. Anteras amarelas

21. Cálice com lacínias internas não claramente definidas e externas subuladas

18. M. langsdorffii

21. Cálice com lacínias internas largamente triangulares e externas triangulares

17. M. jucunda

1. Folhas adultas com face abaxial persistentemente recoberta por indumento

22. Folhas adultas com face abaxial perceptível, não completamente encoberta pelo indumento quando examinada sob lupa

23. Nervuras acródromas basais (Fig. 5)

24. Panículas de glomérulos (Fig. 2) ou escorpióides (Fig. 1)

25. Cálice caduco; panículas de glomérulos

14. M. hyemalis

25. Cálice persistente; panículas escorpióides 31. M. valtherii

24. Panículas não de glomérulos nem escorpióides (Fig. 3)

26. Anteras $0,7-1,3 \mathrm{~mm}$ compr., brancas

16. M. inconspicua

26. Anteras 3-8,5mm compr., amarelas

27. Panículas 2-2,5cm; anteras 3-4,2mm compr.

25. M. ramboi

27. Panículas 4,5-14,3cm; anteras 6-8,5mm compr.

11. M. dodecandra

23. Nervuras acródromas suprabasais (Fig. 6)

28. Indumento nos ramos e inflorescências com tricomas simples mesclados com tricomas

estrelados (Fig. 7)

15. M. ibaguensis

28. Indumento com tricomas não simples (estrelados, dendríticos ou lepidotos; Fig. 9-13)

29. Panículas não glomeruladas (Fig. 3.); anteras amarelas

11. M. dodecandra

29. Panículas de glomérulos (Fig. 2); anteras brancas

30. Face abaxial das folhas com tricomas estrelados (Fig. 9 e 12) e/ou estreladolepidotos (Fig. 13)

31. Folhas com base longamente atenuada 10. M. discolor

31. Folhas com base aguda, arredondada a subcordada 3. M. cabucu

30. Folhas com face abaxial com tricomas dendríticos (Fig. 10) ou estreladoestipitados (Fig. 11), além de eventuais tricomas estrelados (Fig. 9)

32. Folhas com base aguda a atenuada; cálice persistente

13. M. fasciculata

32. Folhas com base subcordada a arredondada; cálice caduco 14. M. hyemalis 
22. Folhas adultas com face abaxial não perceptível, completamente encoberta pelo indumento quando examinada sob lupa

33. Face abaxial das folhas com tricomas aracnóideos (Fig. 8), não individualizáveis ...... 1. M. albicans

33. Face abaxial das folhas com tricomas estrelados (Fig. 9 e 12), dendríticos (Fig. 10), estrelado-estipitados (Fig. 11) ou lepidotos (Fig. 13), sempre individualizáveis

34. Panículas de glomérulos (Fig. 2)

35. Inflorescências com ramos secundários basais curtos, com 1 ou 2 pares de glomérulos ou pontos de ramificação

36. Folhas com base atenuada, nervuras longamente suprabasais (posicionadas 1,2-6cm acima da base). 10. M. discolor

36. Folhas com base aguda, arredondada ou subcordada, nervuras basais ou curtamente suprabasais (posicionadas até $0,5 \mathrm{~cm}$ acima da base)

37. Folhas com face abaxial com tricomas estrelado-estipitados (Fig. 11)

14. M. hyemalis

37. Folhas com face abaxial com tricomas estrelado-lepidotos (Fig. 13), às vezes mesclados com poucos tricomas dendríticos (Fig. 10) 21. M. Iymanii

35. Inflorescências com ramos secundários basais longos, com seqüências de 3 ou mais glomérulos ou pontos de ramificação

38. Nervuras acródromas basais (Fig. 5) 6. M. cinerascens

38. Nervuras acródromas suprabasais (Fig. 6)

39. Ovário com ápice glabro

40. Folhas ovais, elípticas a arredondadas; nervuras $5+2$ ou $7+2$

3. M. cabucu

40. Folhas lanceoladas a linear-lanceoladas, elíptico-lanceoladas ou oblanceoladas; nervuras $3+2$

41. Ramos novos proeminentemente 4-alados

32. M. willdenowii

41. Ramos novos apenas achatados, não 4-alados

5. M. chartacea

39. Ovário com ápice recoberto por tricomas

42. Cálice caduco, com lacínias internas não claramente definidas (ver Fig. 17) 2. M. budlejoides

42. Cálice persistente, com lacínias internas triangulares, claramente definidas (ver Fig. 15)

13. M. fasciculata

34. Panículas não glomeruladas

43. Cálice persistente; anteras amarelas

28. M. stenostachya

43. Cálice caduco; anteras brancas 9. M. cubatanensis

1. Miconia albicans (Sw.) Triana, Trans. Linn. Soc. London. 28: 116. 1871. Sect. Miconia.

Arbustos 0,7-3m alt.; ramos, pecíolos, face abaxial das folhas, inflorescências e hipanto densamente revestidos por tricomas aracnóideos, face adaxial das folhas glabrescente. Folhas com pecíolos $0,5-2 \mathrm{~cm}$ compr.; lâmina 4-16×1,6-6,5cm, discolor, coriácea, oval, elíptica ou oblonga, base arredondada a subcordada, ápice obtuso, agudo a curtamente acuminado, margem crenulada, nervuras $3+2,5$ ou até $5+2$, acródromas basais ou ocasionalmente suprabasais (até $0,3 \mathrm{~cm}$ acima da base). Panículas escorpióides, 4,5-14cm compr., terminais. Flores 5-meras; hipanto 2-2,5mm compr.; cálice persistente, lacínias internas ca. 1mm compr., largamente triangulares, externas não perceptíveis; pétalas 2,5-3×2-2,5mm; estames 10 , levemente dimorfos, anteras 2-3mm compr., brancas, uniporosas, conectivo com apêndice basal amplo, contínuo da região ventral à dorsal ou com 1 cálcar dorsal alargado e 2 aurículas ventrais; ovário 3-locular, glabro, estilete abruptamente alargado no ápice, estigma truncado. Baga imatura rosada, madura verde-jade, 25-35 sementes.

Material selecionado: BRASIL. Paraná: Adrianópolis, XI/1999, Roderjan 1645 (EFC). Antonina, IX/1965, Hatschbach 12759 (MBM, UPCB). Castro, X/1964, Hatschbach 11665 (MBM). Guaraqueçaba, VIII/1993, Athayde 41 (UPCB). Jaguariaíva, XII/1992, Cervi 4029 (MBM, 


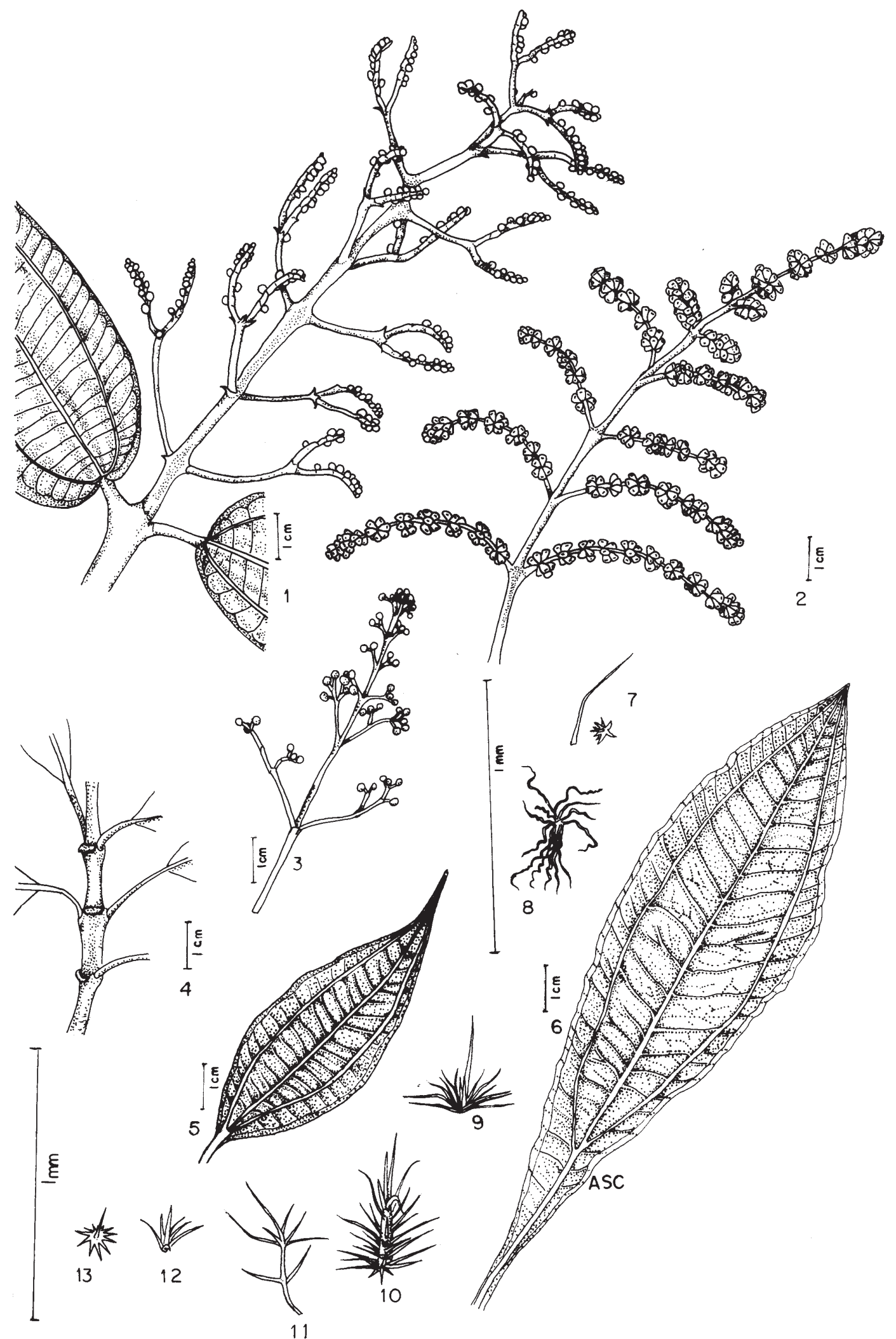

Figuras 1-13. 1. Miconia albicans, panícula escorpióide (Athayde 41). 2. M. fasciculata, panícula de glomérulos (Hatschbach 56127). 3. M. petropolitana, panícula (Kozera 218). 4. M. cinnamomifolia, caule com projeções interpeciolares (Britez 1831). 5. M. petropolitana, folha acródroma basal (Kozera 218). 6. M. discolor, folha acródroma suprabasal (Hatschbach 19087). 7. M. ibaguensis, tricomas simples e estrelado (Silva 1626). 8. M. albicans, tricoma aracnóide (Athayde 41). 9-11. M. ferruginata, respectivamente tricomas estrelado, dendrítico e estrelado-estipitado. 12. M. petropolitana, tricoma estrelado (Kozera 218). 13. M. discolor, tricoma estreladolepidoto (Hatschbach 19087). 


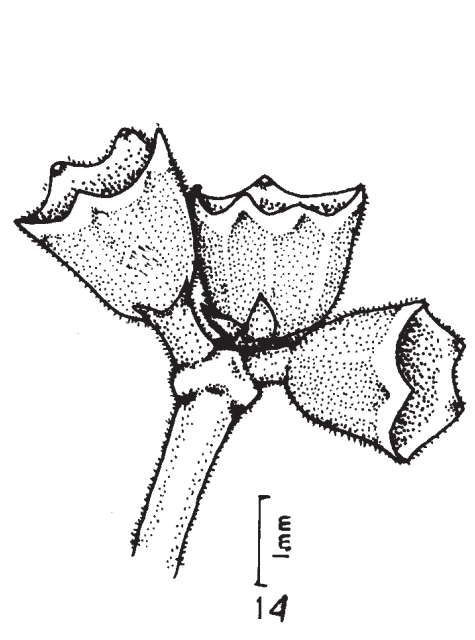

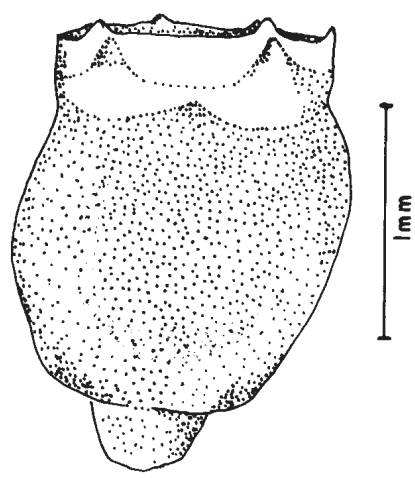

17

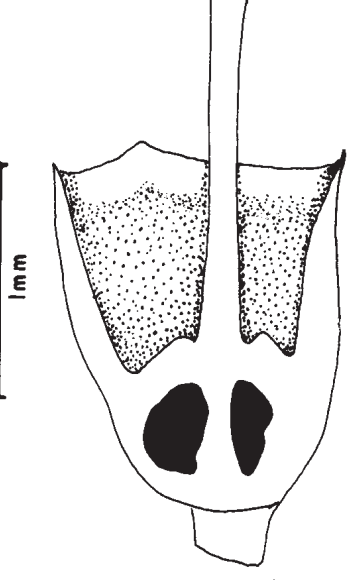

18
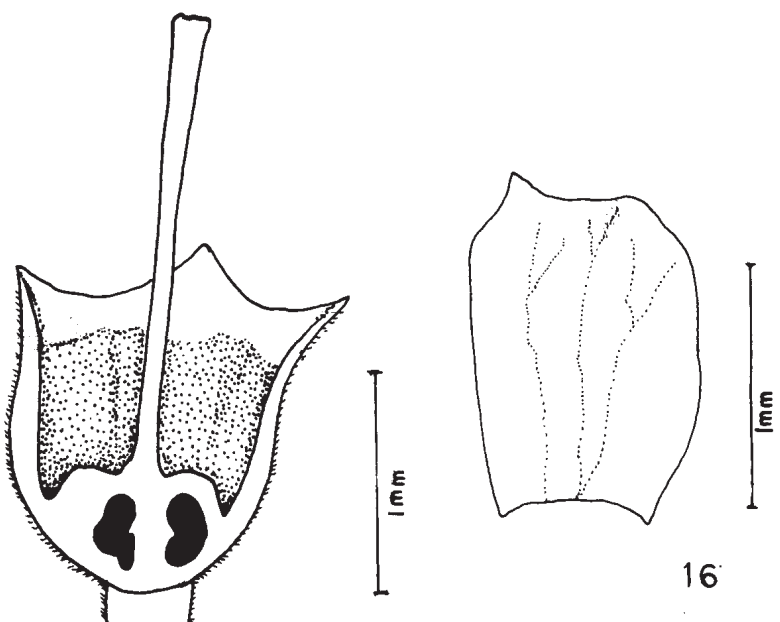

16

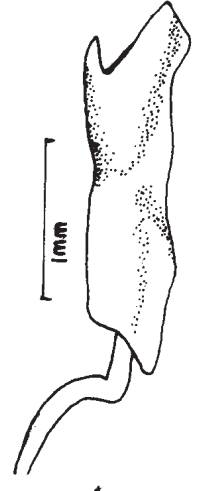

19
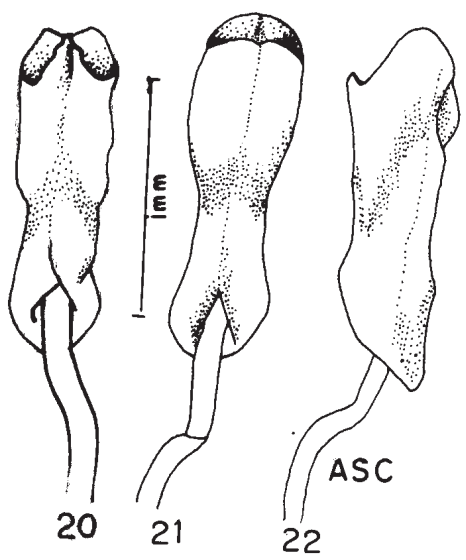

Figuras 14-22. 14-16. Miconia inconspicua, detalhe de unidade da inflorescência, hipanto e ovário em corte longitudinal e pétala (Hatschbach 69819). 17-18. M. collatata, hipanto em vista externa e em corte longitudinal (Hatschbach 14294). 19-22. M. inconspicua, estame antepétalo em vista lateral e ventral e estame antessépalo em vista ventral e lateral (Hatschbach 69819).

UPCB). São Jerônimo da Serra: X/1998, Francisco s.n. (FUEL 22127, MBM). Sengés: X/1971, Hatschbach 27101 (MBM, UPCB). Tibagi, XII/ 1992, Cervi 4007 (MBM, UPCB). Ventania, IX/1998, Silva 2462 (MBM).

Ocorre desde o sul do México e Antilhas até o Paraguai e Paraná. Coletada em Cerrado, vegetação secundária ou sobre afloramentos rochosos e formações litorâneas, com flores e frutos durante praticamente o ano todo.

2. Miconia budlejoides Triana, Trans. Linn. Soc. London 28: 118. 1871. Sect. Glossocentrum.

Arvoretas a árvores ca. 5m alt.; ramos, pecíolos, face abaxial das folhas, inflorescências e hipanto recobertos por tricomas estrelado-lepidotos, às vezes mesclados com tricomas dendríticos curtos, face adaxial das folhas glabrescente. Folhas com pecíolo 2-4,5cm compr.; lâmina 9,6-23,7×3-8,6cm, discolor, cartácea, elíptica a elíptico-lanceolada, base atenuada, ápice acuminado a caudado, margem ondulada e repanda a denticulada, nervuras $3+2$, acródromas suprabasais (0,5-2,7cm acima da base). Panículas de glomérulos, 6-10,7cm compr., terminais, ramos basais com 3-5 pares de glomérulos ou pontos de ramificação. Flores 5-meras; hipanto 2-2,6mm compr.; cálice caduco, lacínias internas 0,7-1mm compr., não claramente definidas, dentículos externos triangulares; pétalas 1,5-2,9×1-1,5mm; estames 10 , isomorfos, anteras 2,5-3mm compr., brancas, uniporosas, conectivo não ou curtamente prolongado, inapendiculado; ovário 2-3 locular, ápice com tricomas, estilete alargado no ápice, estigma truncado. Baga imatura verde, madura enegrecida, 4-9 sementes. 
Material selecionado: BRASIL. Paraná: Doutor Ulysses, XII/1999, Hatschbach 69825 (MBM). Londrina, X/1992, Silva 1541 (FUEL). Morretes, X/1998, Hatschbach 19920 (MBM). Paranaguá, IX/1962, Hatschbach 9307 (MBM, UPCB).

Ocorre desde o Rio de Janeiro até Santa Catarina. Coletada em Floresta Ombrófila Densa e Floresta Estacional, com flores em setembro, outubro e janeiro, com frutos entre dezembro e janeiro.

3. Miconia cabucu Hoehne, Ostenia: 299. 1933. Sect. Glossocentrum.

Árvores 6-10m alt.; ramos, pecíolos, face abaxial das folhas, inflorescências e hipanto densamente recobertos por tricomas estrelado-lepidotos, face adaxial das folhas glabrescente. Folhas com pecíolo 2,5-9,9cm compr.; lâmina 11-25×5,5-17cm, discolor, cartácea, oval, elíptica, raro redonda, base aguda, arredondada a subcordada, ápice obtuso ou agudo até abruptamente acuminado, margem ondulada, nervuras $5+2$ ou 7+2, acródromas suprabasais $(0,2-1,1 \mathrm{~cm}$ acima da base). Panículas de glomérulos, 11,5-29cm compr., terminais, ramos basais com 3-7 pares de glomérulos ou pontos de ramificação. Flores 5-meras; hipanto 3-4mm compr.; cálice caduco, lacínias internas 1-1,5mm compr., não claramente definidas, externas não perceptíveis; pétalas 3-4×2-2,5mm; estames 10 , isomorfos, anteras 3-4mm compr., brancas, uniporosas, conectivo ventralmente bilobulado e dorsalmente tuberculado ou inapendiculado; ovário 3-locular, glabro, estilete levemente filiforme a levemente espessado no ápice, estigma arredondado. Baga imatura verde, madura enegrecida, 3-13 sementes.

Material selecionado: BRASIL. Paraná: Antonina, IX/1986, Cervi 2363 (MBM, UPCB). Guaratuba, X/1957, Hatschbach 4297 (MBM, UPCB). Morretes, IX/1966, Hatschbach 14722 (HUEPG, MBM, UPCB). Paranaguá, X/1986, Britez 1021 (FUEL, MBM). Tunas, IX/2000, Silva 3226 (MBM).

Ocorre desde São Paulo até Santa Catarina. Coletada em Floresta Ombrófila Densa, com flores entre agosto e novembro.

4. Miconia chamissois Naudin, Ann. Sci. Nat. Bot. Ser. 3, 16: 179. 1851. Sect. Miconia.

Arbustos 1,5-2m alt., glabros. Folhas com pecíolo 0,7-2,3 compr.; lâmina 9,2-19,5×3,5-10,3cm, concolor a subconcolor, cartácea, elíptica a largamente oval ou oboval, base abruptamente atenuada, aguda ou obtusa, ápice agudo, acuminado ou raro arredondado, margem inteira a ondulada, nervuras $3+2$, acródromas suprabasais (0,5-1,1cm acima da base). Panículas 13-24,6cm compr., terminais. Flores 5-meras; hipanto 2-2,7mm compr.; cálice persistente, lacínias internas 0,4-0,5mm compr., largamente triangulares ou não claramente definidas, dentículos externos muito reduzidos; pétalas 2,5-3,3×1,8-2,7mm; estames 10 , levemente dimorfos, anteras 2,3-3mm compr., brancas, uniporosas, conectivo prolongado abaixo das tecas, nos antessépalos com apêndice basal amplo, contínuo da região ventral à dorsal, nos antepétalos com cálcar dorsal e aurículas ventrais; ovário 3-5-locular, ápice com tricomas glandulares muito curtos, esparsos, estilete levemente espessado no ápice, glabro ou com tricomas muito curtos, esparsos, estigma truncado a arredondado. Baga imatura verde, madura enegrecida, ca. 30 sementes.

Material selecionado: BRASIL. Paraná: Mal. Cândido Rondon, VII/1965, Hatschbach 13354 (MBM, UPCB). Sengés, V/1977, Hatschbach 39949 (MBM).

Material adicional: BRASIL. São Paulo: Araraquara, XI/1951, Hoehne s.n. (UEC 65125). Paulo de Faria, X/1994, Moncaio et al. 207 (UEC).

Ocorre na Bolívia e Brasil, desde o Mato Grosso, Goiás, Piauí e Ceará até o Paraná. Coletada em locais alagados, em domínio de Cerrado e Floresta Estacional, com flores entre março e outubro.

5. Miconia chartacea Triana, Trans. Linn. Soc. London 28: 119. 1871.

Arvoreta 6m alt.; ramos, pecíolos, face abaxial das folhas, inflorescências e hipanto densamente recobertos por tricomas estrelado-lepidotos, face adaxial das folhas glabrescente. Folhas com pecíolo 1-2,9cm compr.; lâmina 8-18,8×1,9-4,2cm, discolor, cartácea, lanceolada a linear-lanceolada, base aguda a atenuada, ápice agudo a acuminado, margem ondulada, nervuras 3 ou $3+2$, acródromas suprabasais (0,2-0,6cm acima da base). Panículas de glomérulos, ca. $12 \mathrm{~cm}$ compr., terminais, ramos basais com 5-6 pares de glomérulos ou pontos de ramificação. Flores 5-meras; hipanto 2-2,5mm compr.; cálice caduco, lacínias internas ca. 0,7mm compr., triangulares, externas formadas por dentículos agudos; pétalas ca. $2 \times 1,1 \mathrm{~mm}$; estames 10 , isomorfos, anteras ca. $2 \mathrm{~mm}$ compr., brancas, uniporosas, conectivo com um ou dois apêndices dorsais curtos ou inapendiculado; ovário 2-3-locular, glabro, estilete levemente espessado no ápice, estigma arredondado. Baga imatura verde, madura enegrecida, 2-6 sementes. 
Material examinado: BRASIL. Paraná: Guaraqueçaba, V/2002, Scheer et al. s.n. (MBM, UPCB).

Material adicional: BRASIL. São Paulo: Ubatuba, XI/1993, Queiroz et al. 30138 (SPF, UEC).

Ocorre desde a Bahia, Distrito Federal, Minas Gerais e Rio de Janeiro até Santa Catarina. Coletada apenas uma vez no Paraná, em Floresta Ombrófila Densa Montana, com frutos em maio.

A única coleta desta espécie proveniente do Paraná apresenta folhas mais estreitas do que a maioria das coletas feitas nos demais Estados, com folhas elípticas a oblongas. A coleta de Ubatuba acima citada também apresenta a mesma característica, que poderia ser aplicada no reconhecimento das variedades propostas por Cogniaux (1886-1888). Segundo este autor, as variedades angustifolia, longifolia e brevifolia seriam, em parte, delimitadas por suas folhas lanceoladas. Neste trabalho optou-se por não atribuir a identificação no nível de variedade para estas coletas até que estudos mais aprofundados sejam efetuados.

6. Miconia cinerascens Miq., Linnaea 22: 543. 1849. Sect. Glossocentrum.

Chave para as variedades

1. Estames brancos, com filetes eglandulosos var. cinerascens

1. Estames amarelos, com filetes esparsamente glandulosos var. robusta

\subsection{Miconia cinerascens Miq. var. cinerascens}

Arbustos a árvores 1-7m alt.; ramos, pecíolos, face abaxial das folhas, inflorescências e hipanto densamente recobertos por tricomas estrelados ou dendríticos curtos, com eixos clavados, ambas as faces do hipanto, ápice do ovário e, às vezes, base do estilete com projeções glandulares sésseis, diminutas. Folhas com pecíolo 0,8-4cm compr.; lâmina 5-17×1,5-8,5cm, discolor, cartácea a subcoriácea, elíptica, elípticolanceolada a oblongo-lanceolada, base arredondada a atenuada, ápice agudo a acuminado, margem denteada, nervuras 3 ou 3+2, acródromas basais. Panículas de glomérulos, 4-19cm compr., terminais, ramos basais com 3-8 pares de glomérulos ou pontos de ramificação. Flores 5 ou 6-meras; hipanto 2-3mm compr.; cálice caduco, lacínias internas ca. 1mm compr., repandas, externas formadas por dentículos; pétalas 2-3×2mm; estames 10-12, isomorfos, anteras 2-2,5mm compr., brancas, uniporosas, conectivo com um apêndice dorsal ou duas projeções ventrais diminutas; ovário 3-locular, glabro ou com tricomas esparsos no ápice, estilete filiforme, estigma arredondado. Baga imatura vermelha, madura enegrecida, 4-7 sementes.

Material selecionado: BRASIL. Paraná: Apucarana, XI/1999, Pavão s.n. (FUEL 28869). Arapoti, X/1961, Hatschbach 8356 (MBM). Balsa Nova, XI/1980, Hatschbach 43353 (MBM, UPCB). Bituruna, XI/1998, Vergopola s.n. (FUEL 23074). Bocaiúva do Sul, XI/1998, Silva 2594 (MBM). Campo Mourão, XII/1965, Hatschbach 13267 (MBM, UPCB). Cascavel, XI/1988, Cruz 174 (FUEL). Castro, X/1961, Hatschbach 8529 (MBM, UPCB). Cerro Azul, XI/1970, Hatschbach 25578 (MBM, UPCB). Clevelândia, V/1966, Lindeman 1112 (MBM). Contenda, X/1977, Dombrowski 13930 (MBM). Curitiba, XII/1996, Kozera 438 (MBM, UPCB). Foz do Iguaçú, s.d., Lindeman 2957 (MBM). General Carneiro, XII/1966, Hatschbach 15397 (MBM, UPCB). Guarapuava, XI/1973, Hatschbach 33523 (MBM). Imbaú, XII/1994, Kinupp 99 (MBM, UPCB). Irati, X/1970, Carvalho 76 (MBM). Ivaí, V/2000, Dias s.n. (FUEL 26933). Lapa, V/1996, Silva 1667 (MBM, UPCB). Laranjeiras do Sul, III/1967, Lindeman 4678 (MBM). Londrina, X/1994, Silva 1994 (FUEL). Marmeleiro, II/1971, Hatschbach 26449 (MBM). Mauá da Serra, III/1998, Souza s.n. (FUEL 23265). Ortigueira, II/1999, Francisco s.n. (FUEL 28847). Palmas, XII/1989, Hatschbach 53665 (MBM). Palmeira, I/1966, Hatschbach 13488 (MBM). Pinhão, X/1991, Britez 2161 (UPCB). Piraí do Sul, XI/1998, Ribas 2800 (FUEL, MBM). Piraquara, IV/1977, Hatschbach 39875 (MBM, UPCB). Ponta Grossa, XI/1989, Silva 733 (MBM, UPCB). Porto Amazonas, I/1983, Kummrow 2446 (MBM UPCB). Prudentópolis, IV/2003, Goldenberg 591 (UPCB). Quatro Barras, V/1997, Gatti 130 (EFC, UPCB). Rio Branco do Sul, XI/1996, Tiepolo 585 (EFC, MBM). Santa Helena, XII/1977, Hatschbach 40523 (MBM). São Mateus do Sul, XI/1986, Britez 1179 (MBM). Tibagi, X/1959, Hatschbach 6336 (MBM). Tijucas do Sul, XI/1958, Hatschbach 5241 (HUEPG, MBM). União da Vitória, XII/1971, Hatschbach 28152 (MBM). Umuarama, IV/1968, Hatschbach 19037 (UPCB). Ventania, X/1999, Carneiro s.n. (MBM).

Ocorre desde Minas Gerais e Rio de Janeiro até Rio Grande do Sul, Paraguai e norte da Argentina. Coletada em Floresta Ombrófila Mista, Floresta Ombrófila Densa e vegetação secundária, com flores 
entre outubro e fevereiro e em maio, com frutos entre novembro e maio.

Segundo Wurdack (1962), Miconia lagunensis Ule ocorre em Santa Catarina e difere de M. cinerascens pelo ovário com tricomas no ápice. Algumas coletas paranaenses de $M$. cinerascens apresentam tricomas esparsos no ápice do ovário, mas não diferem das demais coletas com relação a outras características e foram mantidas nesta espécie. Vários materiais com folhas tendendo a lanceoladas haviam sido identificados como Miconia paulensis Naudin (espécie dubiamente distinta de $M$. cinerascens, segundo Wurdack 1962 e Martins et al. 1996) e, neste trabalho, foram transferidos para a presente espécie.

6.2. Miconia cinerascens var. robusta Wurdack, Sellowia 14: 153. 1962.

Arbustos a árvores 2-6m alt.; ramos, pecíolos, face abaxial das folhas, inflorescências e hipanto densamente recobertos por tricomas estrelados ou dendríticos curtos, com eixos clavados, hipanto interna e externamente também com projeções glandulares sésseis, diminutas. Folhas com pecíolo 1-3,5cm compr.; lâmina 6-21×2-10cm, discolor, cartácea a subcoriácea, oval, elíptica, oblongo a lanceolada, base arredondada a atenuada, ápice agudo a acuminado, margem denteada, nervuras 3+2, acródromas basais. Panículas de glomérulos, $14-23 \mathrm{~cm}$ compr., terminais, ramos basais com 3-6 pares de glomérulos ou pontos de ramificação. Flores 5-meras; hipanto 3-4mm compr.; cálice caduco, lacínias internas 1-1,5mm compr., repandas, externas formadas por dentículos; pétalas $3,5-4 \times 2,5-3 \mathrm{~mm}$; estames 10 , isomorfos, anteras 3,5-4mm compr., amarelas, uniporosas, conectivo com um apêndice dorsal e duas projeções ventrais, glândulas sésseis esparsas nos filetes e base do conectivo; ovário 3-locular, esparsamente piloso no ápice, estilete filiforme, esparsamente glanduloso ou não, estigma arredondado. Baga imatura verde, madura enegrecida, 20-30 sementes.

Material selecionado: BRASIL. Paraná: Antonina, XII/1964, Kuniyoshi 1063 (MBM). Guaraqueçaba, VII/1993, Lima 54 (MBM, UPCB). Guaratuba, XII/1971, Hatschbach 28529 (MBM). Imbituba, VI/1993, Lima 45 (MBM, UPCB). Morretes, VII/1983, Pizani 34 (EFC, MBM). Paranaguá, XII/1999, Hatschbach 69849 (MBM).

Ocorre desde o Rio de Janeiro e São Paulo até Santa Catarina. Coletada em formações vegetais costeiras, com flores entre novembro e fevereiro e com frutos entre março e julho.
As diferenças entre estas variedades são aparentemente suficientes para que sejam consideradas espécies diferentes, e merecem estudo mais aprofundado e amplo.

7. Miconia cinnamomifolia (DC.) Naudin, Ann. Sci. Nat. Bot. Ser. 3, 16: 168. 1851. Sect. Glossocentrum.

Árvores, raro arbustos, (1,5-)3-15m alt.; ramos com projeções interpeciolares na região dos nós; ramos novos e inflorescências glabras ou com tricomas estrelados esparsos, depois glabros. Folhas com pecíolo 1-2cm compr.; lâmina 5-13×1,5-5,5cm, concolor a subconcolor, cartácea a coriácea, oval, elíptica a lanceolada, base aguda a atenuada, ápice agudo a acuminado, margem ondulada, levemente revoluta e espessada, nervuras 3 ou $3+2$, acródromas suprabasais (até $0,7 \mathrm{~cm}$ acima da base), raramente basais. Panículas 1,5-10,9cm compr., terminais. Flores (4-)5-meras; hipanto 1,5-2mm compr.; cálice caduco, lacínias internas $0,4-0,7 \mathrm{~mm}$ compr., arredondadas, externas formadas por dentículos; pétalas 1,5-2×1mm; estames 8-10, levemente dimorfos, anteras 1,5-2mm compr., brancas, uniporosas, conectivo com apêndice basal amplo, contínuo da região ventral à dorsal ou com 1 calcar dorsal alargado e 2 aurículas ventrais; ovário 3-locular, glabro, estilete abruptamente alargado no ápice, estigma truncado. Baga imatura verde, madura enegrecida, 30-40 sementes.

Material selecionado: BRASIL. Paraná: Antonina, XII/1993, Silva 1280 (HUM, MBM, UPCB). Guaraqueçaba, XII/1991, Hatschbach 56134 (MBM). Guaratuba, XII/1957, Hatschbach 4295 (MBM). Morretes, I/1983, Hatschbach 46032 (MBM). Paranaguá, III/1988, Britez 1831 (FUEL, MBM, UPCB).

Ocorre desde a Bahia até Santa Catarina. Coletada em Floresta Ombrófila Densa e formações costeiras, com flores entre julho e janeiro, com frutos entre dezembro e maio.

As coletas de plantas arbustivas são provenientes de restinga, em locais alagados (Hatschbach 4039 e 34661).

8. Miconia collatata Wurdack, Phytologia 29(2): 145. 1974. Sect. Glossocentrum.

Arbustos, arvoretas até árvores 4-10m alt.; ramos jovens, pecíolos, face abaxial das folhas e inflorescências esparsamente recobertos por tricomas estrelados a dendríticos, depois glabros. Folhas com pecíolo 0,3-2,2cm compr.; lâmina 3,2-16×1,1-5,5cm, concolor a subconcolor, cartácea, elíptica, elíptico- 
lanceolada a lanceolada, base aguda a obtusa, ápice acuminado a curtamente caudado, margem repanda ou remotamente denticulada, nervuras $3+2$, acródromas basais. Panículas 2,6-6cm compr., terminais. Flores 5-meras; hipanto 1,5-2mm compr.; cálice caduco, lacínias internas ca. 0,5mm compr., não definidas, externas formadas por dentículos; pétalas 2-2,5×1-1,5mm; estames 10 , levemente dimorfos, anteras $0,7-1,5 \mathrm{~mm}$ compr., brancas, uniporosas, conectivo prolongado abaixo das tecas, com apêndice dorso-basal amplo, caudado, ou aurículas ventrais e apêndice dorsal curto; ovário 3-locular, glabro, estilete levemente espessado no ápice. Baga imatura verde, madura enegrecida, 2-6 sementes.

Material selecionado: BRASIL. Paraná: Bela Vista do Paraíso, X/1998, Francisco s.n. (FUEL 23675, UPCB). Bocaiúva do Sul, VIII/1960, Hatschbach 7153 (MBM). Cerro Azul, VII/1984, Hatschbach 48110 (MBM). Cianorte, IV/1966, Hatschbach 14294 (MBM, UPCB). Diamante do Norte, IX/1998, Silva 2494 (MBM). Doutor Ulysses, XII/1999, Hatschbach 69801 (MBM, UPCB). Fênix, VII/1996, Mikich s.n. (UPCB 38521). Foz do Iguaçú, VIII/1985, Hatschbach 49564 (MBM, UPCB). Guaíra: VII/1981, Hatschbach 45201 (MBM). Ibiporã, VIII/1997, Cloclet 117 (FUEL, UPCB). Londrina, X/1987, Vieira 205 (FUEL). Porto Rico, IX/2000, Albuquerque 37 (HUM). Primeiro de Maio, VIII/1996, Dias s.n. (FUEL 22609, MBM). Rancho Alegre, X/2000, Pavão s.n. (FUEL 28845).

Ocorre em Goiás, São Paulo, Paraná, Paraguai e Argentina. Coletada em Floresta Ombrófila Densa e Floresta Estacional, com flores entre maio e novembro e com frutos em entre agosto e dezembro.

9. Miconia cubatanensis Hoehne, Anexos Mem. Inst. Butantan, Secç. Bot. 1(5): 139. 1922. Sect. Glossocentrum.

Arbustos a arvoretas 1,7-6m alt.; ramos, pecíolos, face abaxial das folhas, inflorescências e hipanto densamente recobertos por tricomas estrelado-lepidotos. Folhas com pecíolo $0,5-2 \mathrm{~cm}$ compr.; lâmina 4,5-17×1-4,5cm, discolor, cartácea, oval-lanceolada a lanceolada, base aguda a arredondada, ápice longamente acuminado a caudado, margem inteira ou repanda, nervuras $3+2$, acródromas basais, raro suprabasais (até $0,2 \mathrm{~cm}$ acima da base). Panículas 2,5-6,5cm compr., terminais. Flores 5-meras; hipanto 2-2,5mm compr.; cálice caduco, lacínias internas ca. 0,5mm compr., triangulares, externas formados por dentículos; pétalas $2-2,5 \times 0,7 \times 1,1$; estames 10 , isomorfos, anteras $1-1,5 \mathrm{~mm}$ compr., brancas, uniporosas, conectivo com apêndice dorsal longo ou curto; ovário 2-locular, ápice com tricomas estrelados, estilete filiforme, estigma truncado. Baga imatura verde, madura enegrecida, 2-6 sementes.

Material selecionado: BRASIL. Paraná: Bocaiúva do Sul, X/1992, Cordeiro 861 (MBM). Campina Grande do Sul, X/1996, Cordeiro 1316 (MBM). Coroados, VI/1996, Mikich s.n. (UPCB 30195). Guaratuba: II/1959, Hatschbach 5530 (MBM). Matinhos, VII/1977, Hatschbach 40029 (MBM). Morretes, IV/1969, Hatschbach 21321 (FUEL, MBM, UPCB). Paranaguá, V/1968, Hatschbach 19261 (MBM).

Ocorre desde Minas Gerais até Santa Catarina. Coletada em Floresta Ombrófila Densa, com flores entre fevereiro e junho e com frutos entre abril e outubro.

10. Miconia discolor DC., Prodr. 3: 184. 1828. Sect. Glossocentrum.

Arbustos a arvoretas 1-6m alt.; ramos, pecíolos, face abaxial das folhas, inflorescências e hipanto moderada a densamente recobertos por tricomas estrelados e estrelado-lepidotos, às vezes ramos e folhas glabrescentes. Folhas com pecíolo 0,3-2,5cm compr.; lâmina 7,2-28×2,1-11,5cm, discolor ou subconcolor, cartácea, oblanceolada a obovada ou elíptica, base longamente atenuada, ápice obtuso a curtamente acuminado, margem crenulada, nervuras $3+2$, raro 5+2, acródromas suprabasais (1,2-6cm acima da base). Panículas de glomérulos, 7,8-22,1cm compr., terminais, ramos basais com 1-2 pares de glomérulos ou pontos de ramificação. Flores 5-meras; hipanto 2-2,5mm compr.; cálice caduco, lacínias internas ca. 0,5mm compr., não definidas, externas formadas por dentículos inconspícuos; pétalas 2-2,7×1,3-2,2mm; estames 10, isomorfos, anteras 2,5-3,5mm compr., brancas, uniporosas, conectivo inapendiculado ou com 2 aurículas ventrais curtas; ovário 3-locular, glabro, estilete filiforme, estigma arredondado. Baga imatura verde, madura enegrecida, 5-12 sementes.

Material selecionado: BRASIL. Paraná: Apucarana: III/1990, Correa s.n. (FUEL 8172). Arapongas, IV/1998, Francisco s.n. (FUEL 24205, MBM). Bandeirantes, XI/1995, Thomé 576 (MBM). Bela Vista do Paraíso, X/1998, Francisco s.n. (FUEL 23676, UPCB). Cambé, IV/1986, Vieira 47 (FUEL). Castelo do Paraná, VIII/1967, Hatschbach 17073 (MBM). Cerro Azul, VIII/1978, Hatschbach 41564 
(MBM). Cruzeiro do Iguaçú, IV/1999, Silva 2923 (MBM). Cruzeiro do Oeste, XI/1959, Braga 40 (HUEPG, UPCB). Diamante do Norte, XI/2000, Sakuragui 11249 (HUM, UPCB). Dois Vizinhos, IX/1972, Hatschbach 30315 (MBM, UPCB). Doutor Ulysses, X/1993, Hatschbach 59223 (MBM). Fênix, X/1996, Mikich s.n. (HUM, UPCB 30193). Foz do Iguaçú, X/1986, Hatschbach 50633 (MBM, UPCB). Jataizinho, IX/1998, Louzano s.n. (FUEL 28823, MBM). Jundiaí do Sul, VIII/1996, Carneiro 226 (MBM). Laranjeiras do Sul, IX/1968, Hatschbach 19817 (MBM, UPCB). Londrina, IX/1989, Silva 254 (HUM, FUEL, UPCB). Marechal C. Rondon, IV/1968, Hatschbach 19163 (MBM). Maringá, XI/1983, Maria s.n. (HUM 203, UPCB). Medianeira, II/1969, Hatschbach 21106 (MBM, UPCB). Perobal, IV/1968, Hatschbach 19087 (MBM, UPCB). Porto Byington, VI/1966, Lindeman 1754 (MBM). Primeiro de Maio, VIII/1996, Dias s.n. (FUEL 22605, UPCB). Rolândia, VII/1987, Colucci s.n. (FUEL 4767). Santa Amélia, XII/1995, Thomé 648 (MBM). São Jerônimo da Serra, VIII/1999, Medri 828 (FUEL). Serra Dourada, XI/1969, Lange 40 (MBM). Sertanópolis, V/1996, Lerry s.n. (FUEL 18176). Telêmaco Borba, X/1995, Dias s.n. (FUEL 17707).

Ocorre desde Minas Gerais e Rio de Janeiro até Santa Catarina, Paraguai e norte da Argentina. Coletada em Floresta Estacional e Floresta Ombrófila Densa, com flores entre agosto e novembro e com frutos durante praticamente o ano todo.

11. Miconia dodecandra Cogn. in Mart., Fl. bras. 14(4): 243. 1887. Sect. Tamonea.

Arvoretas a árvores 3-8m alt.; ramos jovens, pecíolos, face abaxial das folhas, inflorescências e hipanto moderada a densamente recobertos por tricomas estrelado-estipitados a dendríticos. Folhas com pecíolo 1-6,5cm compr.; lâmina 6-22,3×2,5-10cm, discolor, cartácea, elíptica a elíptico-lanceolada ou ovallanceolada, base arredondada a aguda, ápice agudo a acuminado, margem inteira, nervuras $3+2$ a $5+2$, acródromas basais a curtamente suprabasais (até 0,2cm acima da base). Panículas 5,5-12,4cm compr., terminais. Flores 5 ou 6-meras; hipanto $4,5-5 \mathrm{~mm}$ compr.; cálice persistente, lacínias internas 1,5-2mm compr., triangulares, externas inexistentes; pétalas 6,5-8,5×2,5-3mm; estames 10-12, levemente dimorfos, anteras 6,5-8,5mm compr., amarelas (filetes avermelhados quando velhos), uniporosas, conectivo dorsalmente giboso, espessado a partir do terço inferior da teca, com 2 aurículas ventrais; ovário 3-4-locular, com tricomas no ápice, estilete encurvado, abruptamente alargado no ápice, com tricomas estrelados na metade inferior, estigma arredondado. Baga imatura verde, madura enegrecida, 70-100 sementes.

Material selecionado: BRASIL. Paraná: Antonina, I/1991, Hatschbach 52281 (MBM, UPCB). Guaraqueçaba, I/1995, Athayde 226 (MBM, UPCB). Guaratuba, XI/1967, Hatschbach 17887 (MBM). Morretes, I/1979, Hatschbach 41949 (MBM). Paranaguá: V/1966, Hatschbach 14396 (MBM, UPCB).

Ocorre desde o México até Santa Catarina. Coletada em Floresta Ombrófila e formações costeiras, com flores e frutos durante praticamente o ano todo.

12. Miconia doriana Cogn. in Mart., Fl. bras. 14(4): 376. 1887. Sect. Glossocentrum.

Arbustos 1,2-2m alt.; ramos, face abaxial das folhas, inflorescências e hipanto esparsamente recobertos por tricomas estrelados, depois glabros. Folhas com pecíolo $0,3-1,5 \mathrm{~cm}$ compr.; lâmina 3,7-13,5 $\times 0,8-5 \mathrm{~cm}$, concolor a subconcolor, membranácea, elíptica, oblongo-lanceolada a lanceolada, base aguda, atenuada a abruptamente atenuada, ápice caudado, margem inteira, repanda até denticulada, nervuras $3+2$, acródromas suprabasais (0,2-0,58m acima da base), com domácia na face abaxial. Panículas 2,5-6,3cm compr., paucifloras, terminais e laterais ou apenas terminais. Flores 5-6-meras; hipanto 1,8-2mm compr.; cálice caduco, lacínias internas ca. $1 \mathrm{~mm}$ compr., triangulares, externas curtamente subuladas; pétalas 3,5-4,3×1,6-2,2mm; estames 16-20, isomórficos, anteras 1,5-1,9mm compr., brancas, uniporosas, conectivo prolongado abaixo das tecas, com apêndice dorsal amplo ou dois apêndices ventrais e um dorsal curtos; ovário 2-3-locular, glabro, estilete espessado no ápice, estigma truncado. Frutos e sementes não vistos.

Material selecionado: BRASIL. Paraná: Bocaiúva do Sul, XII/1994, Hatschbach 61390 (MBM). Campina Grande do Sul, XII/1962, Hatschbach 9558 (MBM). São José dos Pinhais, II/1970, Hatschbach 23458 (MBM). Sengés, II/1972, Hatschbach 29222 (MBM).

Ocorre desde o Espírito Santo até Santa Catarina. Coletada em Floresta Ombrófila Densa e Floresta Ombrófila Mista, com flores entre dezembro e fevereiro.

13. Miconia fasciculata Gardn., London J. Bot. 1: 533. 1842. Sect. Glossocentrum. 
Arbustos 2-3m alt.; ramos, pecíolos, face abaxial das folhas, inflorescências e hipanto moderada a densamente recobertos por tricomas estrelados e dendríticos. Folhas com pecíolo 0,7-2cm compr.; lâmina 9,4-22,5×3-6,9cm, subconcolor a discolor, cartácea, lanceolada a elíptico-lanceolada, base aguda a atenuada, raro obtusa, ápice longamente acuminado a caudado, margem remotamente denticulada; nervuras $3+2$ ou $5+2$, acródromas suprabasais $(0,3-0,9 \mathrm{~cm}$ acima da base). Panículas de glomérulos, 11,6-21cm compr., terminais, ramos basais com 4-10 pares de glomérulos ou pontos de ramificação. Flores 4-meras; hipanto 2,1-3mm compr.; cálice persistente, lacínias internas 0,7-1,2mm compr., triangulares, dentículos externos triangulares; pétalas 2-2,8x1,3-1,7mm; estames 8 , isomorfos, anteras 1,1-1,9mm compr., brancas, uniporosas, conectivo prolongado na base, inapendiculado ou com apêndices ventrais diminutos; ovário 3-locular, ápice com tricomas, estilete filiforme, às vezes levemente espessado no ápice. Baga imatura verde, madura enegrecida, 6-12 sementes.

Material selecionado: BRASIL. Paraná: Cerro Azul, 10/1973, Hatschbach 32649 (MBM). Doutor Ulysses, XI/1998, Hatschbach 68876 (MBM, UPCB). Guaraqueçaba, XII/1991, Hatschbach 56127 (MBM, UPCB). Guaratuba, XII/1962, Hatschbach 9435 (MBM). Paranaguá, XI/1994, Ziller 616 (MBM).

Material adicional: BRASIL. Santa Catarina: Itapoá, III/1993, Negrelle A782 (MBM, UPCB). São Paulo: Cananéia, I/1999, Goldenberg 462 (UPCB).

Ocorre desde Minas Gerais e Rio de Janeiro até Santa Catarina. Coletada em Floresta Ombrófila Densa e formações costeiras, com flores entre outubro e dezembro.

A descrição do fruto foi elaborada com base nos materiais de Santa Catarina e São Paulo. Miconia fasciculata difere de $M$. racemifera DC. (que não ocorre no Paraná) pelos tricomas com ramos mais longos e cálice com lacínias mais longas, quase subuladas. O exemplar Hatschbach 69806 (MBM) tem cálice com dentículos um pouco mais compridos que as demais coletas, mas ainda não tão característicos como em $M$. racemifera. A circunscrição destas espécies, incluindo $M$. saldanhaei Cogn., $M$. divaricata Gardner, $M$. fluminensis Ule e M. fasciculata var. catharinensis Wurdack, necessita ser reavaliada.

14. Miconia hyemalis A.St.-Hil. \& Naudin, Ann. Sci. Nat. Bot. Ser. 3, 16: 142. 1851. Sect. Cremanium.
Arbustos a arvoretas 0,7-5m alt.; ramos jovens, pecíolos, face abaxial das folhas e inflorescências moderada a densamente recobertos por tricomas dendríticos ou estrelado-estipitados, hipanto com indumento estrelado. Folhas com pecíolo $0,4-2,4 \mathrm{~cm}$ compr.; lâmina 2,8-13(-16)×1-5,6cm, discolor, cartácea a coriácea, oval, elíptica, oval-lanceolada ou lanceolada, base subcordada a arredondada, ápice agudo a curtamente acuminado, margem denteada, nervuras 3 ou 3+2, acródromas basais a curtamente suprabasais (até $0,3 \mathrm{~cm}$ acima da base). Panículas de glomérulos, 1,7-7(-13,5)cm compr., terminais, ramos basais com 1-2 pares de glomérulos ou pontos de ramificação. Flores 5(-6)-meras; hipanto 2-2,4mm compr.; cálice caduco, com lacínias internas 1-1,8mm compr., longa a curtamente triangulares, externas triangulares; pétalas 1,5-1,8×1,8-2,1mm; estames 10(-12), levemente dimorfos, anteras 1,7-2mm compr., brancas, biporosas, conectivo com dois lobos ventrais e um dorsal, ambos curtos; ovário 3-locular, com tricomas ou raro glabro no ápice, estilete filiforme. Baga imatura verde, madura enegrecida; 10-15 sementes.

Material selecionado: BRASIL. Paraná: Arapoti, III/1968, Hatschbach 18862 (MBM). Balsa Nova, XI/1980, Dombrowski 11958 (MBM). Bocaiúva do Sul, XI/1998, Silva 2619 (MBM). Castro, X/1964, Hatschbach 11685 (HUEPG, MBM, UPCB). Curitiba, X/1995, Carrião s.n. (MBM, UPCB 28407). Guarapuava, IX/1951, Frenzel 676 (MBM). Ipiranga, 8/X/1969, Hatschbach 22370 (MBM). Irati, X/1972, Carvalho 81 (MBM). Jaguariaíva, X/1995, Carrião s.n. (MBM, UPCB 40). Lapa, IX/1982, Kummrow 1974 (MBM). Laranjeiras do Sul, III/1967, Lindeman 4709 (MBM). Palmeira, IX/1981, Dombrowski 12646 (MBM). Paranaguá, XII/1973, Hatschbach 33476 (MBM). Pato Branco, IX/1996, Jamhour 71 (MBM). Pinhão, III/1967, Lindeman 4965 (MBM). Ponta Grossa, IX/1966, Hatschbach 14652 (MBM, UPCB). Quatro Barras, IX/1996, Tiepolo 487 (EFC, UPCB). Reserva, XI/1998, Ferreira s.n. (FUEL 28843). Sengés, IX/1959, Hatschbach 6323 (MBM). Tibagi, IX/1996, Ziller 1490 (MBM). Tijucas do Sul, IX/1986, Silva 171 (HUEPG, MBM, UPCB). Ventania, X/1998, Francisco s.n. (FUEL 23881, UPCB).

Ocorre desde São Paulo até o Rio Grande do Sul e Uruguai. Coletada em Cerrado, vegetação secundária e Floresta Ombrófila Mista, com flores em março e abril e entre agosto e novembro, com frutos entre julho e dezembro.

Miconia hyemalis geralmente tem folhas com superfície tendendo à bulada e nervuras transversais 
em número menor e com espaçamento maior do que as folhas de $M$. lymanii, mas a distinção entre ambas é mais clara quando os tricomas da face abaxial são analisados sob lupa. Em M. lymanii os tricomas são geralmente estrelado-lepidotos, às vezes também com tricomas dendríticos que podem cobrir os estreladolepidotos, enquanto que em $M$. hyemalis os tricomas são estrelado-estipitados, com ramos muito mais longos do que na primeira.

15. Miconia ibaguensis (Bonpl.) Triana, Trans. Linn. Soc. London 28: 110. 1871. Sect. Miconia.

Arbustos 1,5-2m alt.; ramos, pecíolos, inflorescências, hipanto e nervuras na face abaxial das folhas moderada a densamente recobertos por tricomas estrelados e por tricomas simples, folhas com ambas as faces geralmente com tricomas simples, raramente também com tricomas estrelados, depois glabras na face adaxial. Folhas com pecíolo 0,5-1,4cm compr.; lâmina 5-13,7×1,5-5cm, subconcolor, cartácea, às vezes levemente bulada, lanceolada a oval-lanceolada, base arredondada, ápice acuminado e mucronulado, margem serreado-ciliada, nervuras $3+2$ a 5 , acródromas suprabasais (2-4mm acima da base). Panículas de glomérulos, 3,9-12cm compr., terminais. Flores 5-meras; hipanto 2,4-3,4mm compr.; cálice caduco, lacínias internas 0,7-1mm compr., triangulares, externas curtamente subuladas; pétalas 2,5-3,1×1,6-2,1mm; estames 10 , levemente dimorfos, anteras $2-2,7 \mathrm{~mm}$ compr., brancas, uniporosas, conectivo dorsalmente espessado, não prolongado, com 2 apêndices ventrais; ovário 3-locular, com tricomas esparsos no ápice, estilete com tricomas esparsos na base, abruptamente alargado no ápice. Baga imatura verde, madura enegrecida, ca. 100 sementes.

Material selecionado: BRASIL. Paraná: Antonina, X/1993, Hatschbach 59205 (MBM, UPCB). Morretes, II/1996, Silva 1626 (MBM, UPCB).

Ocorre desde o sul do México até o Paraguai e Paraná. Coletada em vegetação secundária de formações costeiras, com flores e frutos entre outubro e fevereiro.

16. Miconia inconspicua Miq., Linnaea 22: 542. 1849. Sect. Cremanium.

Arvoretas ou árvores 4-8m alt.; ramos jovens, pecíolos, face abaxial das folhas, inflorescências e hipanto densa a moderadamente recobertos por tricomas estrelados. Folhas com pecíolo 0,6-2,7cm compr.; lâmina 4,8-13×1,5-4,5, discolor a subconcolor, cartácea, oblongo-lanceolada a lanceolada, base aguda ou obtusa, ápice acuminado, margem denticulada ou denteada, nervuras 3+2, acródromas basais. Panículas 4-9,4cm compr., terminais. Flores 5-meras; hipanto 1,6-1,8mm compr.; cálice persistente, lacínias internas 0,6-1,2mm compr., triangulares ou arredondadas, dentículos externos triangulares, curtos; pétalas 1,5-1,9×1,1-1,4mm; estames 10, levemente dimorfos, anteras $0,7-1,3 \mathrm{~mm}$ compr., brancas, biporosas, conectivo espessado no dorso, curtamente prolongado abaixo das tecas, ventralmente bilobado ou com apêndice basal amplo, contínuo da região ventral à dorsal e trilobado, com um lobo dorsal e dois lobos projetando-se ventralmente; ovário 3-locular, ápice com tricomas, estilete levemente espessado no ápice. Baga imatura verde, madura azulada, 12-16 sementes.

Material selecionado: BRASIL. Paraná: Almirante Tamandaré, X/1989, Dombrowski 14330 (MBM). Bocaiúva do Sul, IX/2000, Silva 3213 (MBM). Cerro Azul, X/1973, Hatschbach 32626 (MBM). Doutor Ulysses, XII/1999, Hatschbach 69819 (MBM). Prudentópolis, IV/2003, Goldenberg 596 (UPCB). Tunas, IX/1997, Silva 1957 (MBM).

Ocorre desde Minas Gerais até o Paraná. Coletada em Floresta Ombrófila Densa e Floresta Ombrófila Mista, com flores em setembro e outubro e com frutos em dezembro e abril.

Vários materiais identificados como $M$. inconspicua var. glabrata Wurdack (descrita para Santa Catarina) pertencem à $M$. petropolitana.

17. Miconia jucunda (DC.) Triana, Trans. Linn. Soc. London 28: 101. 1871. Sect. Jucunda.

Arbustos a arvoretas 2-4,5m alt.; ramos jovens, pecíolos, face abaxial das folhas, inflorescências e hipanto com indumento esparso a moderado ou raramente denso, com tricomas estrelados, geralmente glabrescentes. Folhas com pecíolo 0,7-2cm compr.; lâmina 4-14,2×1,8-5,6cm, concolor a subconcolor, cartácea, elíptica ou oval a lanceolada, base arredondada, raro subcordada, ápice agudo a acuminado, margem inteira ou repanda, nervuras $3+2$ ou 5, acródromas basais a suprabasais (até $0,3 \mathrm{~cm}$ da base). Panículas 4,5-14,3cm compr., terminais. Flores 5-meras; hipanto 3-3,9mm compr.; cálice caduco, lacínias internas 1,7-2mm compr., largamente triangulares, externas triangulares; pétalas 9,5-15mm; estames 10, levemente dimorfos, anteras 6-7,5mm compr., amarelas, uniporosas, conectivo glabro ou com tricomas glandulares muito esparsos, com apêndice dorsal amplo ou com dois apêndices ventrais e um 
dorsal diminutos; ovário 3-locular, glabro, estilete filiforme e encurvado. Baga imatura avermelhada, madura enegrecida, ca. 80 sementes.

Material selecionado: BRASIL. Paraná: Altônia, II/2001, Romagnolo 56 (UPCB). Antonina, XII/1967, Hatschbach 18150 (MBM, UPCB). Guaraqueçaba, XI/1998, Isernhagen 207 (MBM, UPCB). Guaratuba, XII/1998, Borgo 268 (UPCB). Loanda, IV/1969, Hatschbach 5603 (MBM, UPCB). Ribeirão Claro, XI/1995, Dias s.n. (FUEL). Vila Alta, XII/1995, Ziller 1179 (MBM).

Ocorre desde a Bahia até Santa Catarina. Coletada em formações costeiras e à margem do rio Paraná, com flores em fevereiro, abril, novembro e dezembro, com frutos em novembro e dezembro.

As coletas do oeste do Estado (Loanda e Altônia) apresentam ramos, pecíolos e inflorescências com tricomas bem mais densos do que nas demais coletas. Estas coletas assemelham-se a outras efetuadas no Mato Grosso, que vêm sendo identificadas como Miconia staminea DC, da qual $M$. jucunda provavelmente não difere. Os materiais de $M$. staminea coletados no Rio de Janeiro não apresentam o indumento encontrado nos materiais citados acima.

18. Miconia langsdorffii Cogn. in Mart., Fl. bras. 14(4): 232. 1887. Sect. Jucunda.

Arbustos ca. 1m alt.; ramos jovens, pecíolos, inflorescências e hipanto com tricomas estrelados esparsos, depois glabros. Folhas com pecíolo 0,3-0,5cm compr.; lâmina 1,9-6×0,4-1,6cm, concolor, cartácea, lanceolada, base obtusa a arredondada, ápice acuminado, margem serrilhada, nervuras $3+2$, acródromas suprabasais (ca. 0,1cm acima da base). Racemos 1-1,5cm compr., terminais. Flores 5-meras; hipanto 2,8-3mm compr.; cálice caduco, lacínias internas não claramente definidas formando um tubo 0,8-0,9mm, lacínias externas longas, subuladas; pétalas 6,1-7,2×3,2-3,8mm; estames 10, levemente dimorfos, anteras $3,1-4,9 \mathrm{~mm}$ compr., amarelas, uniporosas, conectivo com tricomas glandulares, não prolongado, espessado dorsalmente e com dois apêndices ventrais ou dois ventrais e um dorsal muito curto; ovário 3-locular, glabro, estilete filiforme, encurvado. Baga imatura avermelhada, madura enegrecida, 20-25 sementes.

Material examinado: BRASIL. Paraná: Joaquim Távora, XI/1976, Hatschbach 39284 (MBM).

Material adicional: BRASIL. São Paulo: Assis, XI/1993, Sciamarelli et al. 29023 (UEC). Itirapina, s.d., Goldenberg 28482 (UEC); VIII/1992,
Goldenberg 28492 (UEC). Teodoro Sampaio, XII/1986, Pastore 200 (SP).

Ocorre desde Minas Gerais até o Paraná e Paraguai. Coletada apenas uma vez no Paraná, provavelmente em cerrado, com flores em dezembro.

19. Miconia latecrenata (DC.) Naudin, Ann. Sci. Nat. Bot. Ser. 3, 16: 239. 1851. Sect. Hypoxanthus.

Arbustos a arvoretas 2-5m alt.; ramos, pecíolos, face abaxial das folhas, inflorescências e hipanto esparsamente recobertos por tricomas estrelados, depois glabros. Folhas com pecíolo 0,4-1,4cm compr.; lâmina 7-18,8×2-7,4cm, concolor, membranácea, elíptico-lanceolada a lanceolada, base atenuada a aguda, ápice agudo ou acuminado, raro caudado, margem repanda a denteada, nervuras $3+2$, acródromas basais. Panículas terminais 5,5-8,9cm compr. e laterais $2-8,5 \mathrm{~cm}$ compr.. Flores 5-meras; hipanto 1,1-1,9mm compr.; cálice caduco, lacínias internas $0,3-0,6 \mathrm{~mm}$ compr., largamente triangulares, dentículos externos muito reduzidos; pétalas $1-1,8 \times 0,7-1,2 \mathrm{~mm}$; estames 10 , isomorfos, anteras 1-1,7mm compr., brancas, com poro muito amplo e inclinado (à semelhança de uma rima), atingindo ca. $75 \%$ do seu comprimento, conectivo basalmente prolongado, com um apêndice dorsal e dois ventrais curtos e arredondados ou apenas com os ventrais; ovário 3-locular, ápice glabro ou esparsamente recoberto por tricomas estrelados, estilete espessado ou levemente espessado no ápice. Baga imatura verde, madura enegrecida, 10-20 sementes.

Material selecionado: BRASIL. Paraná: Antonina, I/1968, Hatschbach 18285 (MBM). Arapongas, VI/1988, Hirosse s.n. (FUEL 6351, UPCB). Calógeras, III/1994, Hatschbach 60535 (MBM). Doutor Ulysses, VIII/2002, Hatschbach (MBM). Guaraqueçaba, I/1998, Gatti 243 (EFC, UPCB). Morretes, IV/1989, Hatschbach 52748 (MBM). Paranaguá, II/1968, Hatschbach 18613 (MBM). Pinhão, III/1967, Lindeman 4866 (MBM). Sapopema, IV/1997, Kinupp 364 (FUEL, UPCB).

Ocorre desde o Piauí até o Rio Grande do Sul. Coletada em Floresta Ombrófila ou formações costeiras, raramente em Floresta Ombrófila Mista, com flores entre janeiro e julho, com frutos entre abril e agosto.

20. Miconia ligustroides (DC.) Naudin, Ann. Sci. Nat. Bot. Ser. 3, 16: 167. 1851. Sect. Glossocentrum.

Arbustos a árvores 0,5-6m alt.; ramos, pecíolos, folhas, inflorescências e hipanto com tricomas 
estrelados diminutos, esparsos, depois glabros. Folhas com pecíolo 0,2-0,6cm compr.; lâmina 2,4-10×1,1-4cm, concolor a subconcolor, elíptica, oblonga a elípticolanceolada, lanceolada, base aguda, arredondada, truncada até subcordada, ápice obtuso, agudo a acuminado, margem inteira ou repanda, levemente revoluta, nervuras 3 ou $3+2$, acródromas basais a curtamente suprabasais (até $0,2 \mathrm{~cm}$ acima da base). Panículas 3,5-6,6cm compr., terminais. Flores 5-meras; hipanto 1,5-2mm compr.; cálice caduco, lacínias internas 0,5-0,7mm compr., arredondadas a largamente triangulares, dentículos externos muito reduzidos; pétalas 2,2-2,5×1,2-2,1mm; estames 10 , levemente dimorfos, anteras 1,9-2,7mm compr., brancas, uniporosas, conectivo com apêndice basal amplo ou com um apêndice dorsal e dois ventrais; ovário 3-locular, glabro, estilete espessado ou levemente espessado no ápice. Baga imatura verde, madura enegrecida, 10-20 sementes.

Material selecionado: BRASIL. Paraná: Arapoti, II/1987, Hatschbach 50907 (MBM, UPCB). Curitiba, XI/1977, Landrum 2470 (MBM). Jaguariaíva, XII/1992, Cervi 4035 (MBM, UPCB). Palmeira, I/1966, Hatschbach 13482 (MBM, UPCB). Piraí do Sul, IV/1987, Kuniyoshi 5155 (EFC, MBM). Rio Branco do Sul, XI/1978, Hatschbach 41814 (MBM, UPCB). São Jerônimo da Serra, III/1988, Silveira s.n. (FUEL 5359, UPCB). Sengés, IX/1959, Hatschbach 6264 (MBM). Tibagi, I/1996, Schütz 15 (EFC, UPCB).

Ocorre desde Ceará até Santa Catarina. Coletada em Cerrado, vegetação secundária e brejos, com flores e frutos durante praticamente o ano todo.

21. Miconia lymanii Wurdack, Sellowia 14: 164. 1962. Sect. Cremanium.

Arbustos a arvoretas 1-5m alt.; ramos jovens, pecíolos, face abaxial das folhas, face adaxial apenas nas folhas novas, inflorescências e hipanto densamente recobertos por tricomas estrelado-lepidotos sésseis ou curtamente estipitados, mesclados ou não com tricomas dendríticos esparsos a densos. Folhas com pecíolo 0,8-1,9cm compr.; lâmina 2,9-12×0,9-4cm, discolor, coriácea, elíptica, elíptico-lanceolada ou lanceolada, base aguda ou estreitamente arredondada, ápice agudo, acuminado a curtamente caudado, margem inteira, repanda ou denticulada, nervuras $3+2$ ou 5 , acródromas basais a curtamente suprabasais (até $0,5 \mathrm{~cm}$ acima da base). Panículas de glomérulos, 3,7-11,3cm compr., terminais, ramos basais com 1-2 pares de glomérulos ou pontos de ramificação. Flores (4-)5-meras; hipanto 2-2,5mm compr.; cálice caduco, com lacínias internas 1,1-1,4mm compr., arredondadas a triangulares, externas curtamente triangulares; pétalas 1,6-1,9×1,6-1,8; estames 8-10, isomorfos, anteras 1,3-1,8mm compr., creme, curtamente oblongas, biporosas, conectivo dorsalmente espessado, basalmente prolongado, com dois apêndices ventrais e um dorsal, todos triangulares, curtos; ovário 2-4-locular, ápice glabro, estilete filiforme. Baga imatura vermelha, depois enegrecida, 1-6 sementes.

Material selecionado: BRASIL. Paraná: Campina Grande do Sul, X/1997, Ribas 1949 (MBM). Guaratuba, XII/1997, Fernandes 64 (MBM). Morretes, I/1995, Ribas 764 (MBM). Ponta Grossa, X/1999, Ziller 1947 (MBM). Quatro Barras, IV/1990, Ribas 304 (FUEL, MBM, UPCB). São José dos Pinhais, XI/1965, Hatschbach 13132 (MBM, UPCB). Tijucas do Sul, XII/1997, Ribas 2145 (MBM).

Ocorre desde São Paulo até Santa Catarina. Coletada em Floresta Ombrófila Densa Montana ou Alto-montana, com flores em novembro e dezembro frutos entre janeiro e abril.

Comentários: ver $M$. hyemalis.

22. Miconia petropolitana Cogn. in Mart., Fl. Bras. 14(4): 613. 1888. Sect. Glossocentrum.

Arbustos a árvores 1,5-5(-10)m alt.; ramos jovens, inflorescências e hipanto esparsa a moderadamente recobertos por tricomas estrelados diminutos, depois glabros. Folhas com pecíolo 0,4-1,6cm compr.; lâmina $2,1-11,5 \times 0,9-4 \mathrm{~cm}$, concolor a subconcolor, membranácea, elíptica, oval, elíptico-lanceolada ou lanceolada, base atenuada a aguda, raro obtusa, ápice agudo, acuminado a caudado, margem repanda a dentada, nervuras 3 ou $3+2$, acródromas basais. Panículas 1,5-6cm compr., terminais. Flores 5-meras; hipanto 1,6-1,9mm compr.; cálice persistente, lacínias internas 0,5-0,6mm compr., triangulares, dentículos externos triangulares, curtos; pétalas 1,1-2,1× 1,2-1,3mm; estames 10, levemente dimorfos, anteras $1,2-2,1 \mathrm{~mm}$ compr., brancas, uniporosas, conectivo giboso, prolongado abaixo das tecas, com um apêndice dorsal afilado ou amplo, às vezes bilobado ou trilobado; ovário 3-4-locular, levemente estrelado-furfuráceo no ápice, estilete levemente espessado no ápice. Baga imatura verde, madura azulada a enegrecida, 9-22 sementes.

Material selecionado: BRASIL. Paraná: Bituruna, IX/1998, Vergopola s.n. (FUEL 23076). Campina Grande do Sul, IX/1962, Hatschbach 9273 (MBM, UPCB). Campo Largo, IX/1976, Dombrowski 6365 (MBM). Castro, VII/1998, Souza s.n. (FUEL 21974). Colombo, VI/1995, Maschio 50 (MBM). Curitiba, 
XI/1996, Kozera 386 (MBM, UPCB). Lapa, IX/1982, Kummrow 1967 (MBM). Londrina, IX/1989, Silva 237 (FUEL, UPCB). Piraquara, VIII/1992, Ziller 207 (EFC, MBM). Prudentópolis, IV/2003, Goldenberg 586 (UPCB). Reserva, VIII/1997, Paiva s.n. (FUEL 22976). Rio Branco do Sul, IX/1996, Tiepolo 681 (EFC, MBM). Rio Negro, X/1957, Hatschbach 4298 (MBM). São Jerônimo da Serra, X/1995, Silva 237 (FUEL). São João do Triunfo, VII/1966, Lindeman 1925 (MBM). São Mateus do Sul, II/1987, Britez 1363 (MBM). Sapopema, IV/1997, Kinupp 359 (FUEL, UPCB). Sengés, II/1995, Souza 36 (MBM). Telêmaco Borba, Vieira 496 (FUEL). Tibagi, IX/1996, Ziller 1520 (MBM). Tijucas do Sul, VIII/1958, Hatschbach 4989 (MBM).

Ocorre desde Minas Gerais e Rio de Janeiro até Santa Catarina e Paraguai. Coletada em Floresta Ombrófila Densa, Floresta Ombrófila Mista e Floresta Estacional, com flores entre agosto e outubro e com frutos durante praticamente $\mathrm{o}$ ano todo.

Algumas coletas com folhas tendendo a ovais, com base obtusa, margem fortemente dentada e nervuras muito próximas entre si haviam sido identificadas como M. inconspicua var. glabrata Wurdack. Esta variedade necessita ser reavaliada, mas as flores aqui analisadas mostram que certamente este conjunto de coletas pertence a $M$. petropolitana.

23. Miconia prasina (Sw.) DC., Prodr. 3: 188. 1828. Sect. Miconia.

Arbustos a arvoretas 1-2m alt.; ramos novos, pecíolos, folhas novas, inflorescências e hipanto moderada a densamente revestidos por tricomas estrelados, depois glabros. Folhas com pecíolo 0,3-0,8cm compr., alado; lâmina 4,1-11,9×1,4-4,2cm, subconcolor a discolor, cartácea, elíptica a elípticolanceolada, base atenuada, ápice agudo ou obtuso, margem denticulada na metade distal, nervuras 3+2 ou 5, acródromas suprabasais (0,4-1,2cm acima da base). Panículas 6,4-9,6cm compr., terminais. Flores 5-meras; hipanto 2,8-3mm compr.; cálice persistente, lacínias internas 0,9-1,2mm compr., dentículos externos reduzidos; pétalas 2,4-3,1×1,7-2,1mm; estames 10 , levemente dimorfos, anteras 1,8-2,8mm compr., brancas, uniporosas, conectivo muito espessado no dorso, com 2 apêndices ventrais amplos; ovário 2-3-locular, ápice com tricomas curtos, estilete espessado no ápice. Baga imatura verde, madura enegrecida, sementes 50-80.

Material selecionado: BRASIL. Paraná: Guaíra, IV/1968, Hatschbach 19135 (MBM); V/1981,
Buttura 663 (MBM). São Jorge do Patrocínio, II/2001, Takeda 50 (UPCB).

Material adicional: BOLÍVIA: Beni: Ballivian, XI/1990, Lewis 37997 (MBM). BRASIL: Mato Grosso do Sul: Aquidauana, XI/1989, Pott 5312 (MBM). Taquaruçu, XII/1992, Souza 38 (HUM); VIII/1992, Souza 604 (HUM).

Ocorre desde a América Central e Caribe até o Paraguai e Paraná. Coletada na beira de rios no oeste do Estado, com flores em abril e maio.

O material proveniente de São Jorge do Patrocínio (oeste do Estado) apresenta folhas menores, pecíolo alado e inflorescências com tricomas mais densos do que os demais materiais, da mesma forma que coletas provenientes do litoral, desde São Paulo até Guianas e Venezuela. Materiais com estas características foram segregados por Cogniaux (1891) em M. prasina var. attenuata (DC.) Cogn. e M. paraguariensis Cogn., mas devem representar apenas extremos de variação de uma espécie com ampla distribuição e altamente polimórfica (Wurdack 1973).

24. Miconia pusilliflora (DC.) Naudin, Ann. Sci. Nat. Bot. Ser. 3, 16: 171. 1851. Sect. Hypoxanthus.

Arbustos $1,5 \mathrm{~m}$ a árvores até $15 \mathrm{~m}$ alt.; ramos, pecíolos, ambas as faces das folhas novas, inflorescências e hipanto densa a esparsamente recobertos por indumento estrelado-furfuráceo, posteriormente glabros ou não. Folhas com pecíolo 0,5-1,5cm compr.; lâmina 4-17×1,5-5cm, concolor ou subconcolor, membranácea a cartácea, elíptica a oblonga, oboval ou lanceolada, base atenuada ou arredondada, ápice caudado, margem inteira a denticulada ou serreada, nervuras $3+2$, acródromas basais a curtamente suprabasais (até $0,3 \mathrm{~cm}$ acima da base), na face abaxial livres ou unidas à base da nervura central por membrana. Panículas 4-16cm compr., terminais. Flores 4 ou 5-meras, raro 6-meras; hipanto 1,5-2mm compr.; cálice caduco, lacínias internas 0,3-0,4mm compr., triangulares, agudas, externas triangulares ou constituídas por dentículos reduzidos; pétalas 1,5-2,3×1-1,3mm; estames 8-10, isomorfos, anteras 1-1,5mm compr., brancas, com deiscência longitudinal ampla, desde o ápice até a base das tecas, conectivo levemente prolongado, inapendiculado; ovário 3-locular, glabro ou furfuráceo no ápice, estilete levemente espessado no ápice. Baga imatura verde, madura enegrecida, 2-3(-6) sementes.

Material selecionado: BRASIL. Paraná: Amaporã, IV/1988, Goetzke 255 (MBM, UPCB). 
Apucarana, VIII/1997, Saraiva s.n. (FUEL 28868). Arapongas, IX/1997, Vidal s.n. (FUEL 28871). Balsa Nova, IV/1975, Hatschbach 36655 (MBM). Bela Vista do Paraíso, V/1998, Francisco s.n. (FUEL 22020, MBM). Campina Grande do Sul, V/1963, Hatschbach 9980 (MBM, UPCB). Cornélio Procópio, IX/1999, Francisco s.n. (FUEL 28876). Coroados, VI/1996, Mikich s.n. (UPCB 30196). Fênix, VII/1997, Mikich s.n. (MBM, UPCB 32299). Guaraqueçaba, VI/1993, Lima 26 (MBM, UPCB). Guaratuba, V/1996, Svolenski 117 (EFC, MBM). Ibiporã, VIII/1997, Cloclet s.n. (FUEL 22957, HUEPG, UPCB). Imbaú, VII/1998, Francisco s.n. (FUEL 21853, UPCB). Jaguariaíva, VI/1993, Portes 98 (EFC). Londrina, 1978, Lima 532 (MBM). Morretes, V/1966, Hatschbach 14462 (MBM, UPCB). Paranaguá, III/1986, Souza 83 (MBM, UPCB). Perobal, VI/1967, Hatschbach 16635 (MBM). Piraquara, V/1998, Dittrich 365 (MBM). Rancho Alegre, V/2000, Pavão s.n. (FUEL 28844). Rolândia, IV/1999, Estevan 18 (FUEL). São José dos Pinhais, V/1990, Nicolack 121 (MBM, UPCB). São Sebastião da Amoreira, II/1999, Francisco s.n. (FUEL 28834). Sapopema: XII/1990, Pimenta s.n. (FUEL 12560). Sertanópolis, V/1990, Pereira s.n. (FUEL 8874). Telêmaco Borba, IX/1990, Silva s.n. (FUEL 11007). Terra Boa, V/1969, Hatschbach 21552 (MBM). Tibagi, VIII/1995, Paiva s.n. (FUEL 17563, HUM, MBM). Umuarama, IV/1968, Hatschbach 19037 (MBM). Ventania, VII/1998, Paiva s.n. (FUEL 24260, HUEPG).

Ocorre desde o Espírito Santo e Minas Gerais até o Rio Grande do Sul, Argentina e Paraguai. Coletada em Floresta Ombrófila, Floresta Ombrófila Mista, Floresta Estacional, formações costeiras e vegetação secundária, com flores entre fevereiro e junho e com frutos entre fevereiro e outubro.

Goldenberg \& Martins (in prep.) consideraram $M$. rigidiuscula Cogn. e $M$. hymenonervia (Raddi) Cogn. como sinônimos de M. pusilliflora.

25. Miconia ramboi Brade, Sellowia 8: 376. 1957. Sect. Amblyarrhena.

Arbustos ca. 3m alt.; ramos, pecíolos, face abaxial das folhas, inflorescências e hipanto moderada a densamente recobertos por tricomas estrelados ou curto estipitados, às vezes glabrescentes. Folhas com pecíolo 0,3-0,7cm compr.; lâmina 2,5-7×0,5-1,5cm, subconcolor a discolor, cartácea, elíptico-lanceolada a oblongolanceolada, base aguda ou atenuada, ápice agudo a obtuso, margem denticulada no terço distal, nervuras 3, acródromas basais. Panículas depauperadas, 2-2,5cm compr., terminais. Flores 6-meras; hipanto 2,9-4,9mm compr.; cálice persistente, lacínias internas 1,3-1,7mm compr., triangulares, externas triangulares; pétalas 6-8,3×2,3-3,4mm; estames 10-12, levemente dimorfos, anteras $3-4,2 \mathrm{~mm}$ compr., amarelas, uniporosas, conectivo inapendiculado ou com um apêndice dorsal curto; ovário 3-4-locular, glabro, estilete encurvado, levemente espessado no ápice. Baga madura imatura verde, madura enegrecida, 15-25 sementes.

Material selecionado: BRASIL. Paraná: Campina Grande do Sul, IX/1999, Barbosa 372 (MBM). General Carneiro, X/1966, Hatschbach 14979 (MBM, UPCB). Palmas, XI/1972, Hatschbach 30733 (MBM, UPCB). Tijucas do Sul, IX/1997, Silva 1999 (MBM).

Ocorre desde o Paraná até o Rio Grande do Sul. Coletada em Floresta Ombrófila Mista, com flores em junho e entre setembro e novembro, com frutos em novembro.

26. Miconia sellowiana Naudin, Ann. Sci. Nat. Bot. Ser. 3, 16: 206. 1851. Sect. Hypoxanthus.

Arbustos $2 \mathrm{~m}$ até árvores $15 \mathrm{~m}$ alt.; ramos, pecíolos, ambas as faces das folhas novas, inflorescências e hipanto moderada a esparsamente recobertos por indumento estrelado-furfuráceo, depois glabros. Folhas com pecíolo 0,5-1cm compr.; lâmina 5-11×1-3cm, concolor a subconcolor, cartácea a membranácea, lanceolada a oblongo-lanceolada, base atenuada e decurrente, ápice acuminado a caudado, margem distintamente serreada exceto no terço inferior, nervuras 3 ou $3+2$, acródromas suprabasais $(0,5-1,7 \mathrm{~cm}$ acima da base), em geral unidas à base da nervura central por membrana. Panículas 4-8cm compr., terminais. Flores 5-meras; hipanto 1,3-1,8mm compr.; cálice caduco, lacínias internas 0,2-0,3mm compr., arredondadas, externas estreitamente triangulares; pétalas $1,4-1,8 \times 1-1,4 \mathrm{~mm}$; estames 10 , isomorfos, anteras ca. $2 \mathrm{~mm}$ compr., brancas, com abertura ventral muito ampla (à semelhança de uma rima) atingindo ca. 1/3 do compr. da teca, conectivo levemente prolongado, com 2 lobos ventrais diminutos; ovário 3-locular, sem tricomas mas papiloso no ápice, estilete levemente espessado no ápice. Baga imatura amarela, madura enegrecida, 6-9 sementes.

Material selecionado: BRASIL. Paraná: Adrianópolis, VII/1987, Hatschbach 51285 (MBM, UPCB). Campo Largo, X/1996, Svolenski 391 (EFC, MBM). Clevelândia, IV/1966, Lindeman 1073 (MBM). Curitiba, 12/IX/1996, Kozera 196 (UPCB). Curiúva, VIII/2000, Pavão s.n. (FUEL 28878). 
Guaratuba, VIII/1988, Silva 542 (MBM, UPCB). Jaguariaíva, VII/1992, Silva s.n. (EFC, MBM, UPCB 25695). Lapa, IX/1970, Kuniyoshi 2378 (MBM). Mauá da Serra: IX/1999, Pavão s.n. (FUEL 28849). Morretes, VIII/1983, Silva 702 (MBM). Paranaguá, X/2002, Silva 3733 (MBM). Palmeira, IX/1981, Dombrowski 12642 (MBM). Piraquara, XI/1972, Imaguire 3121 (MBM). Ponta Grossa, IX/1966, Hatschbach 14649 (MBM, UPCB). Rio Branco do Sul, VII/1980, Hatschbach 43046 (MBM, UPCB). São Jerônimo da Serra, VIII/1998, Cavalheiro s.n. (FUEL 25388). São José dos Pinhais, VIII/1966, Hatschbach 14599 (MBM). Telêmaco Borba, XI/1996, Uejima 42 (FUEL). Tibagi, IX/1996, Ziller 1570 (MBM). Tijucas do Sul, IX/1957, Hatschbach 4065 (MBM, UPCB). Ventania, X/1998, Cavalheiro s.n. (FUEL 23883, UPCB).

Ocorre desde Goiás e Minas Gerais até o Rio Grande do Sul. Coletada em Cerrado, Floresta Ombrófila Densa e Floresta Ombrófila Mista, com flores em fevereiro e entre maio e dezembro, com frutos entre agosto e janeiro e em maio.

27. Miconia splendens (Sw.) Griseb., Fl. Brit. W. Indian Is. 256. 1860. Sect. Miconia.

Árvores ca. $5 \mathrm{~m}$ alt.; ramos novos, pecíolos, face abaxial das folhas novas e nervuras nas folhas maduras, inflorescências e hipanto moderada a esparsamente revestidos por tricomas estrelados. Folhas com pecíolo 0,4-1,2cm compr.; lâmina 18-27,7×6,5-12cm, subconcolor, membranácea a cartácea, elíptica, base atenuada e decurrente, ápice acuminado a curtocaudado, margem denticulada, nervuras $3+2$ ou 5 , acródromas suprabasais (1-1,5cm acima da base). Panículas 10-14,7cm compr., terminais. Flores com pedicelo 6-7mm, 5-meras; hipanto 2,8-3,6mm compr.; cálice caduco, lacínias internas 1,1-1,3mm compr., dentículos externos reduzidos; pétalas 2,8-3,3× 0,9-1,4mm; estames 10, levemente dimorfos, anteras 2,9-4,1mm compr., brancas, uniporosas, conectivo espessado no dorso, com 2 lobos ventrais e um apêndice dorsal curto presente ou não; ovário 3-locular, ápice com tricomas curtos, estilete filiforme, encurvado, levemente espessado no ápice. Baga imatura amarela, madura enegrecida, 35-45 sementes.

Material examinado: BRASIL. Paraná: Diamante do Norte, VIII/1998, Silva 2496 (MBM). Porto Rico, VI/1997, Souza 1994 (HUM). Xambrê, VI/1966, Lindeman 1676 (MBM).

Ocorre desde o sul do México até a Bolívia, Mato Grosso do Sul e Paraná. Coletada em Floresta
Estacional, geralmente acompanhando rios, com flores em junho e frutos em agosto.

Miconia splendens provavelmente ocorre no Estado de São Paulo, porém não teve sua presença confirmada em levantamento realizado para a "Flora Fanerogâmica do Estado de São Paulo”, uma vez que não está documentada em herbários.

28. Miconia stenostachya DC., Prodr. 3: 181. 1828. Sect. Miconia.

Arbustos ca. 1,5m alt.; ramos, pecíolos, face abaxial das folhas, inflorescências, brácteas, bractéolas e hipanto densamente revestidos por tricomas estrelados. Folhas com pecíolo 0,4-0,9cm compr.; lâmina 3,2-9,5×1,2-4cm, discolor, cartácea a coriácea, elíptica a elíptico-lanceolada, base obtusa, arredondada a subcordada, ápice arredondado a levemente acuminado, margem crenulada, nervuras $3+2$ ou $5+2$, acródromas basais. Panículas escorpióides, 4-8cm compr., terminais. Flores 5-meras; hipanto 2,1-2,9mm compr.; cálice persistente, lacínias internas 0,6-1,2mm compr., largamente triangulares, dentículos externos muito reduzidos; pétalas 2,7-3×1,5-1,8mm, margem ciliado-glandulosa; estames 10, levemente dimorfos, anteras 2,7-3,8mm compr., amarelas, uniporosas, conectivo espessado no dorso, não prolongado abaixo das tecas, com um calcar dorsal e dois lobos ventrais diminutos; ovário 3-locular, papiloso, estilete filiforme, encurvado, com tricomas glandulares esparsos, estigma truncado. Baga imatura verde, madura enegrecida, 35-45 sementes.

Material examinado: BRASIL. Paraná: Arapoti, X/1968, Hatschbach 20029 (MBM). Sengés, X/1958, Hatschbach 5075 (MBM).

Ocorre desde o sul do México até a Bolívia, Mato Grosso do Sul e Paraná. Coletada em Cerrado, com flores e frutos em outubro.

29. Miconia theaezans (Bonpl.) Cogn. in Mart., Fl. Bras. 14(4): 419. 1888. Sect. Cremanium.

Arbustos $0,6-2 \mathrm{~m}$ a raramente arvoretas $8 \mathrm{~m}$ alt., glabros. Folhas com pecíolo 0,4-2,6cm compr.; lâmina 1,5-14×0,5-4,5cm, concolor a subconcolor, cartácea a subcoriácea, obovada, elíptica a elíptico-lanceolada, base atenuada ou arredondada, ápice acuminado, margem serrilhado-ciliada, nervuras 3 ou $3+2$, acródromas basais. Panículas 4-9cm compr., terminais. Flores 5-meras; hipanto 1,3-1,7mm compr.; cálice persistente, lacínias internas $0,4-0,6 \mathrm{~mm}$ compr., arredondadas, dentículos externos triangulares; pétalas $1,2-1,5 \times 1,1-1,4$; estames 10 , isomorfos, anteras 
0,7-1,1mm compr., brancas, 4-porosas, conectivo prolongado, com dois apêndices ventrais curtos e uma expansão dorsal; ovário 3-locular, glabro, estilete espessado no ápice. Baga imatura verde, madura azulada, ca. 40 sementes.

Material selecionado: BRASIL. Paraná: Antonina, I/1992, Hatschbach 56165 (MBM). Campina Grande do Sul, I/1969, Hatschbach 20965 (MBM, UPCB). Campo Largo, XI/1983, Kummrow 2398 (MBM). Guaraqueçaba, XII/1992, Athayde 11 (UPCB). Guaratuba, XII/1981, Kummrow 1644 (MBM). Jaguariaíva, I/1973, Hatschbach 31137 (MBM). Lapa, X/1980, Dombrowski 14286 (MBM). Londrina, XI/1998, Francisco s.n. (FUEL 26417). Morretes, XI/1964, Hatschbach 11908 (MBM, UPCB). Palmeira, XI/1986, Hatschbach 50832 (MBM, UPCB). Piraí do Sul, XI/1976, Hatschbach 39219 (MBM). Ponta Grossa, X/1965, Hatschbach 12873 (MBM, UPCB). São Jerônimo da Serra: X/1998, Francisco s.n. (FUEL 21121). Sengés, XII/1958, Hatschbach 5378 (MBM). Tamarana. X/1986, Vieira 118 (FUEL). Tibagi: XII/1992, Cervi 3977 (MBM, UPCB).

Ocorre desde a América Central até Santa Catarina. Coletada geralmente brejos ou vegetação secundária em todas as formações vegetais, com flores e frutos durante praticamente o ano todo.

30. Miconia tristis subsp. australis Wurdack, Sellowia 14: 160. 1962. Sect. Glossocentrum.

Arbustos a arvoretas 1,5-5m alt.; nós dos ramos jovens e das inflorescências recobertos por tricomas estrelados diminutos, face adaxial das folhas glabra ou com tricomas simples, esparsos. Folhas com pecíolos 0,3-1,7cm compr.; lâmina 3,6-16×1,3-4,5cm, subconcolor a discolor, membranácea, elíptica a elíptico-lanceolada, base curta a longamente atenuada, ápice acuminado a caudado; margem serreada e setuloso-ciliada, nervuras 3 ou $3+2$, acródromas suprabasais (0,1-1,5cm acima da base). Panículas terminais e laterais, 2-7cm compr. Flores 5-meras; hipanto 1-1,8mm compr.; cálice caduco, lacínias internas $0,5-0,7 \mathrm{~mm}$ compr., largamente triangulares, dentículos externos muito reduzidos; pétalas 1,7-2,2×0,8-1,2mm; estames 10 levemente dimorfos, anteras 1,7-2,6mm compr., brancas, uniporosas, conectivo prolongado na base, espessado, com um apêndice dorsal curto e aurículas ventrais diminutas ou apenas com o apêndice dorsal; ovário 3-locular, papiloso, estilete filiforme ou levemente espessado no ápice. Baga imatura verde, madura enegrecida, 5-8 sementes.
Material selecionado: BRASIL. Paraná: Campo Largo, III/1968, Hatschbach 18990 (MBM). Guaraqueçaba, III/1999, Gatti 210 (UPCB). Guaratuba, III/1996, Ribas 1346 (MBM). Londrina, IV/1993, Vasconcelos 1 (FUEL). Morretes, VIII/1983, Silva 693 (MBM, UPCB). Quatro Barras, IV/1990, Sobral 6207 (MBM).

Ocorre desde São Paulo até Santa Catarina. Coletada em Floresta Ombrófila Densa e Floresta Ombrófila Mista, com flores entre dezembro e abril e com frutos entre março e agosto.

31. Miconia valtherii Naudin, Ann. Sci. Nat. Bot. Ser. 3, 16: 155. 1851. Sect. Miconia.

Arbustos a arvoretas ca 2,5m alt.; ramos jovens, pecíolos, face abaxial das folhas, inflorescências e hipanto moderada a densamente recobertos por tricomas estrelados e dendríticos, face adaxial glabrescente. Folhas com pecíolo 0,7-1,5cm compr.; lâmina 8,4-19,4×3,6-10,8cm, discolor, cartácea a subcoriácea, elíptica a lanceolada, base atenuada, aguda a arredondada, ápice acuminado, remotamente denticulada no terço distal, nervuras $3+2$, acródromas basais. Panículas escorpióides, 9,5-22,6cm compr., terminais. Flores 5(-6)-meras; hipanto 2-2,3mm compr.; cálice persistente, lacínias internas 1-1,2mm compr., triangulares, dentículos externos muito reduzidos; pétalas ca. 2,6x1,8mm; estames 10(-12), levemente dimorfos, anteras 1,3-1,6mm compr., brancas, uniporosas, conectivo longamente prolongado abaixo das tecas, com calcar dorsal curto e 2 aurículas ventrais ou apenas 2 aurículas ventrais; ovário trilocular, papiloso, estilete abruptamente alargado no ápice. Baga imatura castanha, madura enegrecida, 30-50 sementes.

Material examinado: BRASIL. Paraná: Campina Grande do Sul, XII/1972, Hatschbach 23951 (MBM). Guaraqueçaba, IV/1995, Ziller 800 (MBM). Cerro Azul, II/1961, Hatschbach 7719 (MBM, UPCB).

Material adicional: BRASIL. Santa Catarina: Vidal Ramos: III/1958, Reitz 6589 (MBM).

Ocorre desde Minas Gerais e Rio de Janeiro até Santa Catarina (Wurdack 1962, citada como M. eichlerii Cogn.). Coletada em Floresta Ombrófila Densa, com flores entre dezembro e abril, e frutos em abril.

Os frutos foram descritos com base no material de Santa Catarina.

As coletas Hatschbach 7719 e 23951 estavam identificadas em herbário como M. eichlerii Cogn., espécie semelhante a $M$. valtherii, e da qual provavelmente não difere. Este complexo de espécies, 
incluindo M. mellina DC., M. pulchra Cogn. e M. pseudo-eichlerii Cogn., necessita de reavaliação.

32. Miconia willdenowii Naudin, Ann. Sci. Nat. Bot. 3 (16): 199. 1851. Sect. Glossocentrum.

Arbustos ca. 2,5m alt.; ramos novos proeminentemente 4-alados, mais velhos achatados e com uma linha longitudinal em cada lado; ramos, pecíolos, face abaxial das folhas, inflorescências e hipanto recobertos por tricomas estrelados a estrelado-lepidotos, às vezes mesclados com tricomas dendríticos curtos, face adaxial das folhas glabrescente. Folhas com pecíolo 1-2,3cm compr.; lâmina 6,4-16,9×2,1-6,1cm, discolor, cartácea, elíptico-lanceolada ou oblanceolada, base longamente atenuada, ápice acuminado, margem inteira ou repanda, nervuras $3+2$, acródromas suprabasais (0,9-3,1 $\mathrm{cm}$ acima da base). Panículas de glomérulos, 8,6-11,5cm compr., terminais, ramos basais com 3-8 pares de glomérulos ou pontos de ramificação. Flores 5-meras; hipanto 2,1-2,5mm compr.; cálice caduco, lacínias internas $0,5-0,6 \mathrm{~mm}$ compr., não claramente definidas, dentículos externos muito reduzidos; pétalas $1,8-2,1 \times 1,1-1,2 \mathrm{~mm}$; estames 10 , anteras brancas, isomorfas, 1,2-2mm compr., uniporosas, conectivo pouco prolongado, inapendiculado; ovário 3 locular, glabro, estilete filiforme. Baga imatura pardacenta, madura enegrecida; sementes não vistas.

Material examinado: BRASIL. Paraná: Morretes, I/2000, Pasdiora 63 (UPCB); I/2000, Pasdiora 68 (MBM).

Material adicional: BRASIL. São Paulo: São Paulo, IX/1921, Lemos 7529 (SP, US).

Ocorre em Minas Gerais, Rio de Janeiro, São Paulo e Paraná. Coletada em Floresta Ombrófila Alto-montana, com restos de flores e frutos em janeiro.

As descrições de flores foram elaboradas com base no material de Morretes e complementadas com base no material de São Paulo. Os frutos descritos (Pasdiora 63) estão galhados, não permitindo a análise das sementes.

\section{Agradecimentos}

Ao Prof. Olavo Guimarães e ao Dr. Gerdt Hatschbach, pela leitura crítica do manuscrito; à Andrea Castagini, pelas ilustrações.

\section{Referências bibliográficas}

Angely, J. 1965. Flora Analítica do Paraná. São Paulo, Edições Phyton.

Baumgratz, J.F.A. 1980. Miconias do município do Rio de Janeiro. Seção Miconia DC. (Melastomataceae). Rodriguésia 32: 73-95.

Baumgratz, J.F.A. 1982. Miconias do Estado do Rio de Janeiro. Seção Tamonea (Aubl.) Cogn. (Melastomataceae). Arquivos do Jardim Botânico do Rio de Janeiro 26: 69-86.

Baumgratz, J.F.A. 1984. Miconias do Estado do Rio de Janeiro. Seção Chaenanthera Naud. (Melastomataceae). Rodriguésia 36: 45-58.

Clausing, G. \& Renner, S.S. 2001. Molecular Phylogenetics of Melastomataceae and Memecylaceae: implications for character evolution. American Journal of Botany 88: 486-498.

Cogniaux, A. 1886-1888. Melastomataceae. In: C.F.P. Martius; A.G. Eichler \& I. Urban (eds.). Flora Brasiliensis 14(4). Lipsiae, Munique.

Cogniaux, A. 1891. Melastomataceae. In: A. \& C. de Candolle (eds.). Monographiae Phanerogamarum. Paris, G. Masson.

IAPAR, 1994. Cartas Climáticas do Estado do Paraná. Documento 18: 1-45.

Maack, R. 1968. Geografia física do Estado do Paraná. Curitiba, BADEP/UPFR/IBTP.

Martins, A.B., Semir, J., Goldenberg, R. \& Martins, E. 1996. O Gênero Miconia Ruiz et Pav. no Estado de São Paulo. Acta Botanica Brasilica 10: 267-316.

Pereira, E. 1964. Flora do Estado da Guanabara IV. Melastomataceae II. Miconieae. Gênero Miconia. Arquivos do Jardim Botânico do Rio de Janeiro 18: 183-214.

The New York Botanical Garden. Index Herbariorum . Disponível em http://sciweb.nybg.org/ science2/ IndexHerbariorum.asp. Acesso em 27.IV.2004.

Wurdack, J.J. 1962. Melastomataceae of Santa Catarina. Sellowia 14: 109-217.

Wurdack, J.J. 1973. Melastomataceae. In: T. Lasser (ed.). Flora de Venezuela, v.8. 